\title{
Architecture of Rod and Cone Circuits to the On-beta Ganglion Cell
}

\author{
Peter Sterling, Michael A. Freed, ${ }^{a}$ and Robert G. Smith \\ Department of Anatomy, University of Pennsylvania, Philadelphia, Pennsylvania 19104
}

\begin{abstract}
Photoreceptors connect to the on-beta ganglion cell through parallel circuits involving rod bipolar (RB) and cone bipolar (CB) neurons. We estimated for a small patch in the area centralis of one retina the 3-dimensional architecture of both circuits. This was accomplished by reconstructing neurons and synapses from electron micrographs of 189 serial sections.

There were (per $\mathrm{mm}^{2}$ ) 27,000 cones, 450,000 rods, 6500 $\mathrm{CBb}_{1}, 30,300 \mathrm{RB}, 4100$ All amacrines, and 2000 on-beta ganglion cells. The tangential spread of processes was determined for each cell type, and, with the densities, this allowed us to calculate the potential convergence and divergence of each array upon the next. The actual numbers of cells converging and diverging were estimated from serial sections, as were the approximate numbers of chemical synapses involved.
\end{abstract}

The cone bipolar circuit showed narrow convergence and divergence:

$$
\begin{aligned}
16 \text { cones } & \rightarrow 4 \mathrm{CBb}_{1} \rightarrow 1 \text { on-beta } \\
1 \text { cone } & \rightarrow 1 \mathrm{CBb}_{1} \rightarrow 1.2 \text { on-beta }
\end{aligned}
$$

This circuit is thought to contribute significantly to the onbeta cell's photopic receptive field because the $\mathrm{CBb}_{1}$ has a center-surround receptive field whose center diameter is greater than the spacing between adjacent $\mathrm{CBb}_{1} \mathbf{s}$. Consequently, the receptive fields of the $\mathrm{CB}_{1} \mathrm{~s}$ converging on a beta cell are probably largely concentric and thus mutually reinforcing in their contributions to the on-beta.

The rod bipolar circuit showed a wider convergence and divergence:

$$
\begin{aligned}
& 1500 \text { rods } \rightarrow 100 \mathrm{RB} \rightarrow 5 \mathrm{AII} \rightarrow 4 \mathrm{CBb}_{1} \rightarrow 1 \text { on-beta } \\
& 1 \operatorname{rod} \rightarrow \quad 2 \mathrm{RB} \rightarrow 5 \mathrm{AII} \rightarrow 8 \mathrm{CBb}_{1} \rightarrow 2 \rightarrow 2 \text { on-beta }
\end{aligned}
$$

The $\mathbf{1 5 0 0}$ rods converging via this circuit account for the spatial extent of the beta cell's dark-adapted receptive field.

\footnotetext{
Received Feb. 11, 1987; revised June 10, 1987; accepted July 7, 1987

This work was supported by NIH Grants EY00828, EY01583, and training grants to M.F. (T32EY07035) and R.S. (GM-07517). We thank Dr. Barbara McGuire for the preparation of the series on which this paper is based and for the first reconstructions. We are especially grateful to April Firstencel, John Megill, and Ellen Magyarits for technical help and also to Jacqueline Michaud, Donna Heany, and Christian Fahlman for their contributions. Thanks also to Suzanne Leahy for art work and to Judy Jackson for typing. C. Fahlman was supported by a Fight for Sight Student Fellowship, Fight for Sight, Inc., New York, NY. We are grateful to Professor $\mathbf{R}$. Rodiek for his thoughtful reading of the manuscript and for helpful suggestions.

Correspondence should be addressed to Peter Sterling at the above address.

a Present address: National Institutes of Health, Bldg. 36, Room 2C02, Bethesda, MD 20025.

Copyright (C) 1988 Society for Neuroscience $0270-6474 / 88 / 020623-20 \$ 02.00 / 0$
}

This convergence also accounts for the ganglion cell's maintained discharge, which is thought to arise from about 6 quantal "dark events" per second. This many dark events would appear in the ganglion cell if each rod in the circuit contributed 0.004 dark events per second, and this is close to what has been measured in monkey rods (Baylor et al., 1984). Divergence in this circuit serves to expand the number of copies of the quantal signal ( $1 \mathrm{rod} \rightarrow 8\left(\mathrm{CBb}_{1}\right)$ and so to engage large numbers of chemical synapses that provide amplification. Reconvergence at the last stage $\left(8 \mathrm{CBb}_{1} \rightarrow 2\right.$ on-beta) may reduce (by signal averaging) the synaptic noise that would otherwise accumulate along the pathway.

This paper concerns 2 parallel pathways in cat retina that connect photoreceptors to the on-beta ganglion cell (Fig. 1). The linear structure of each pathway has been determined over the last decade (reviewed by Sterling, 1983; Kolb and Nelson, 1984), and the responses of the component elements have been recorded (Nelson, 1982; Kolb and Nelson, 1983; Nclson and Kolb, 1983). It has been proposed, on the basis of these and modeling studies (Smith et al., 1986), that the 2 pathways serve the ganglion cell over different ranges of background light intensity. Rods as well as cones connect to the cone bipolar pathway, which is thought to serve the photopic and mesopic ranges. Rods alone connect to the rod bipolar pathway, which is thought to serve the scotopic range (Smith et al., 1986).

One would like to understand more about the relation between the anatomical structure of these pathways and their functional properties. What anatomical connections, for example, account for the spatial extent of the ganglion cell receptive field? An answer would require knowledge of the connections in 2 dimensions at each stage along the pathway because the receptive field is 2-dimensional. Further, what anatomical connections might contribute to the ganglion cell's extraordinary response of 2-3 spikes to a single quantal event and to its maintained discharge in the dark? The answers would require knowledge of the divergent connections from one rod along the 5-stage pathway to the ganglion cell and also knowledge of the convergent connections of many rods along the same pathway. Knowledge in 2 dimensions of convergent and divergent connections along a pathway we refer to as a "schematic circuit."

Described here are schematic circuits for the cone bipolar and rod bipolar pathways. We first determined for each of the component cell types the structure of its 2-dimensional array, i.e., the distribution density of the cell bodies and the tangential spread of the processes. From this we calculated, assuming circular dendritic and axonal fields (Wässle and Riemann, 1978), the maximum potential convergence and divergence of each array upon the next. The maximum potential connections between arrays are not necessarily fully realized, however, partly 


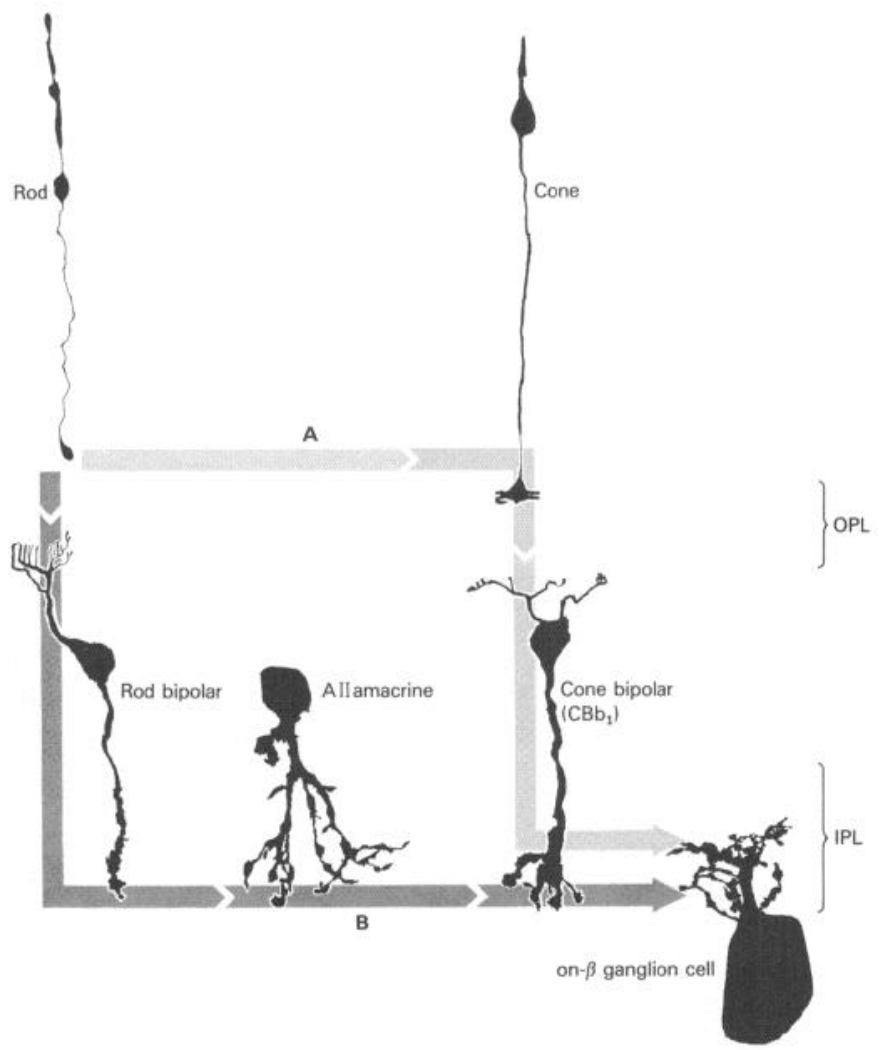

Figure 1. Two identified pathways to the on-beta ganglion cell. Neurons are represented schematically after reconstructions [by McGuire et al. $(1984,1986)$ and Golgi drawings from Kolb and Nelson (1984)]. $A$, Cone bipolar pathway: rod and cone signals mix in the cone axon terminal and are then conveyed to the type $\mathrm{CBb}_{1}$ cone bipolar and thence to the ganglion cell. $B$, Rod bipolar pathway: rod signal is conveyed to the rod bipolar and thence to the AII amacrine interneuron. The AII contacts the $\mathrm{CBb}_{1}$ axon terminal, which thus serves both pathways.

because the dendritic and axonal fields of certain arrays are not circular. Therefore, we also studied the actual convergence and divergence of neurons at each stage and the numbers of synaptic contacts between individual neurons.

This study was accomplished by reconstructing the arrays and connections from electron micrographs of serial, ultrathin sections. We relied mainly on one series of 189 sections cut radially through the area centralis and checked certain points in other material. This series has been prepared and photographed by Dr. B. McGuire, who used it to establish cone bipolar pathways to the beta cells (McGuire et al., 1984, 1986); the rod bipolar pathway in this material was added subsequently (Sterling, 1983). The reason for focusing on a small region of one retina was that the structure of each array shifts markedly with eccentricity, particularly in the area centralis (Steinberg et al., 1973; Boycott and Wässle, 1974; Wässle et al., 1981). Since it seemed likely that the quantitative significance of each array would be found in relation to all the others, it was important to collect as much information as possible from the same locus. After presenting and documenting the schematic circuits in the Results section, we return in the Discussion to consider their possible contributions to function.

\section{Materials and Methods}

The fragment of retina studied here was taken from an adult cat, anesthetized and perfused with a buffered mixture of glutaraldehyde and paraformaldehyde. A block of tissue containing the area centralis was prepared for electron microscopy and cut into a series of 189 radial sections estimated to be $0.075 \mu \mathrm{m}$ thick. Each section was photographed at $1600 \times$. The initial reconstructions from this tissue (McGuire et al. 1984,1986 ) were performed on a computer-assisted video system (Stevens et al., 1980a). Subsequent reconstructions were performed simply by tracing profiles in successive sections onto acetate sheets aligned on a cartoonist's jig. The aligned profiles were subsequently digitized, stacked by the computer, and drawn with the hidden lines removed by a computer-controlled $X-Y$ plotter.

The computer offered an important advantage in the present study. Much of the information that we sought concerned the spread and overlap of processes in the tangential plane. The reconstructions were performed in the vertical plane, but once a cell's profiles had been digitized and entered into the computer, it was easy to obtain the tangential view. (For additional technical details, consult Stevens et al., 1980a; McGuire et al., 1984, 1986.)

\section{Results}

The region studied was a rectangular strip $(300 \times 14.2 \mu \mathrm{m})$ located 400-500 $\mu \mathrm{m}$ temporal to the center of the area centralis (McGuire et al., 1984). In physiological terms, this is about $2^{\circ}$ from the fixation point on the horizontal meridian. At this location, the cell types forming the vertical pathways illustrated in Figure 1 are known to have tangential spreads of no more than about $35 \mu \mathrm{m}$ (Boycott and Wässle, 1974; Kolb et al., 1981, Figs. 1, 2; Vaney, 1985); therefore, the full diameter of a cell's arborization parallel to the plane of section would be included in the series, provided that its soma was located reasonably close to the midpoint of the width of the strip. Thus, the 3 pieces of structural information we were seeking for each array-distribution density, tangential spread, and synaptic connectionswere contained within the strip. The schematic diagrams finally estimated for the cone bipolar and rod bipolar circuits are presented in Figures 2 and 3. The rest of this section presents the data upon which these estimates are based.

\section{Structure of the arrays}

For each cell type we identified every member contained within a given array (Fig. 4). If the type was densely distributed (rods) we studied only a small region; if it was more sparsely distributed (AII, beta cells), we studied the full area photographed for the series. The location of every identified cell was plotted in the tangential plane, and the mean distance to the nearest-neighbor was determined for the array (Wässle and Riemann, 1978). A perimeter was drawn at half the nearest-neighbor distance to the outermost cells in the array, and the area so enclosed (shading, Fig. 4) was used to calculate the density. This method is reasonably accurate where the array is fairly regular. The densities were also calculated by the method of Sterio (1984). The results were similar. The Sterio method gave somewhat lower estimates for the rods, rod bipolars, and cones, but the ratios of their densities, which are used in subsequent estimates (see Table 1), were very close. The tangential spread of each cell type was determined by reconstructing one or more of its members and rotating the reconstruction to obtain the tangential view (Fig. 5). The tangential spread was taken as the diameter of the circle that circumscribed the most widely spread branches. This view also allowed us to estimate the completeness of the reconstruction because it showed where the processes of a given cell had been truncated as they projected beyond the thickness of the series.

Rods. Sixty-four adjacent axon terminals ("spherules") were identified. They were closely packed in the outer plexiform layer, 


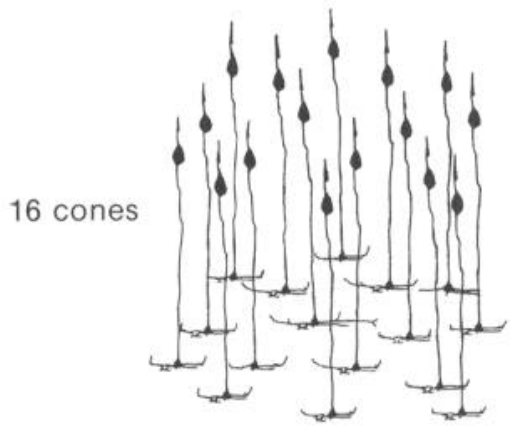

$4 \mathrm{CBb}_{1}$ cone bipolars

$1 \mathrm{On}-\mathrm{X} / \mathrm{beta}$ ganglion cell
Divergence
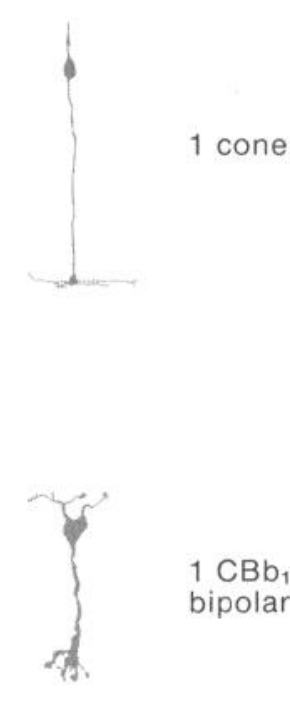

$1 \mathrm{CBb}_{1}$ cone

bipolar

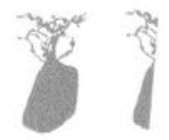

Figure 2. Schematic diagram of the cone bipolar circuit. Functional architecture treated in the Discussion. forming roughly 3 tiers, with a mean nearest-neighbor distance (measured center-to-center in the tangential plane) of $1.9 \pm 0.9$ $\mu \mathrm{m}$ and a distribution density of $450,000 / \mathrm{mm}^{2}$ (Fig. 4). Three rod spherules were reconstructed (Fig. 5). These were about 4 $\mu \mathrm{m}$ in diameter; however, their sites of gap junction contact with cones (Kolb, 1977; Smith et al., 1986) and invagination by rod bipolar dendrites (Boycott and Kolb, 1973; Freed et al., 1987) was restricted to a small region about $0.5 \mu \mathrm{m}$ in radius. Therefore, in subsequent calculations the spherule was considered to be without tangential spread and was treated as a point.

Cones. Twenty-one adjacent cone axon terminals ("pedicles") were identified. They were loosely packed in the outer plexiform layer, just deep to the tiers of rod spherules, with a mean nearestneighbor distance of $5.8 \pm 0.9 \mu \mathrm{m}$ and a distribution density of $27,000 / \mathrm{mm}^{2}$ (Fig. 4). Three pedicles were reconstructed with particular attention to tracing their basal processes. These ramify among the rod spherules with which they form gap junctions. The spread of these processes in the tangential plane averaged $11 \mu \mathrm{m}$ (Fig. 5). The cone pedicles contained about 12 synaptic ribbons in agreement with Boycott and Kolb (1973), which we observed to be distributed in the tangential plane within an elliptical region about $4.4 \mu \mathrm{m}$ in average diameter. The anatomical coverage factor (density $\times$ field area; Wässle and Riemann, 1978) for cones was 2.5 when the basal processes were included and 0.4 when only the distribution of ribbons was considered.

Rod bipolar neurons. Twenty-eight adjacent rod bipolar cells were identified in the region of the series directly underlying the identified cone pedicles. The rod bipolars were recognized by their relatively small somas and dark cytoplasm. They occupied the middle third of the inner nuclear layer (Fig. 6) and had a mean nearest-neighbor distance of $4.9 \pm 1.5 \mu \mathrm{m}$ and a density of $30,000 / \mathrm{mm}^{2}$ (Fig. 4). The dendritic arborizations of $3 \mathrm{rod}$ bipolars were reconstructed (Fig. 7) and found to have an average tangential spread of $12 \mu \mathrm{m}$ (Fig. 5). The coverage factor was 3.4. The axon terminals of 3 rod bipolars in sublamina $b$ of the inner plexiform layer had been reconstructed previously (McGuire et al., 1984). Their synaptic outputs were distributed in the tangential plane within an elliptical region about $6 \mu \mathrm{m}$ in diameter (Fig. 4).

AII amacrine cells. All of the AII amacrine cells in the full patch of retina were identified. They were recognized by their stout processes descending to sublamina $b$ of the inner plexiform layer (Figs. 6 and 8 ) and by their large, lobular appendages in sublamina $a$ (Famiglietti and Kolb, 1975). There were 18 AII cells with a mean nearest-neighbor distance of $15.1 \pm 4.9 \mu \mathrm{m}$ and a density of $4100 / \mathrm{mm}^{2}$ (Fig. 4). We constructed an AII cell that was situated near the center of the series [Fig. 8, AII(1)]. The tangential view (Fig. 5) shows that 2 branches extended in the long axis of the retinal strip and were complete within the series. Other branches extended along the short axis and were incomplete within the series. The circle encompassing the complete branches was $32 \mu \mathrm{m}$ in diameter, which we take as the tangential spread of the AII at this eccentricity (Fig. 5). The coverage factor was 3.3. A second cell [Fig. 8, AII(2)] was reconstructed for the purpose of studying the synaptic connections. It was less complete in the tangential plane, being closer to the edge of the series, and was therefore not used in calculating the potential connections.

$C B b_{1}$ bipolars. All of the type $\mathrm{CBb}_{1}$ cone bipolar axons in the 


\section{Convergence}
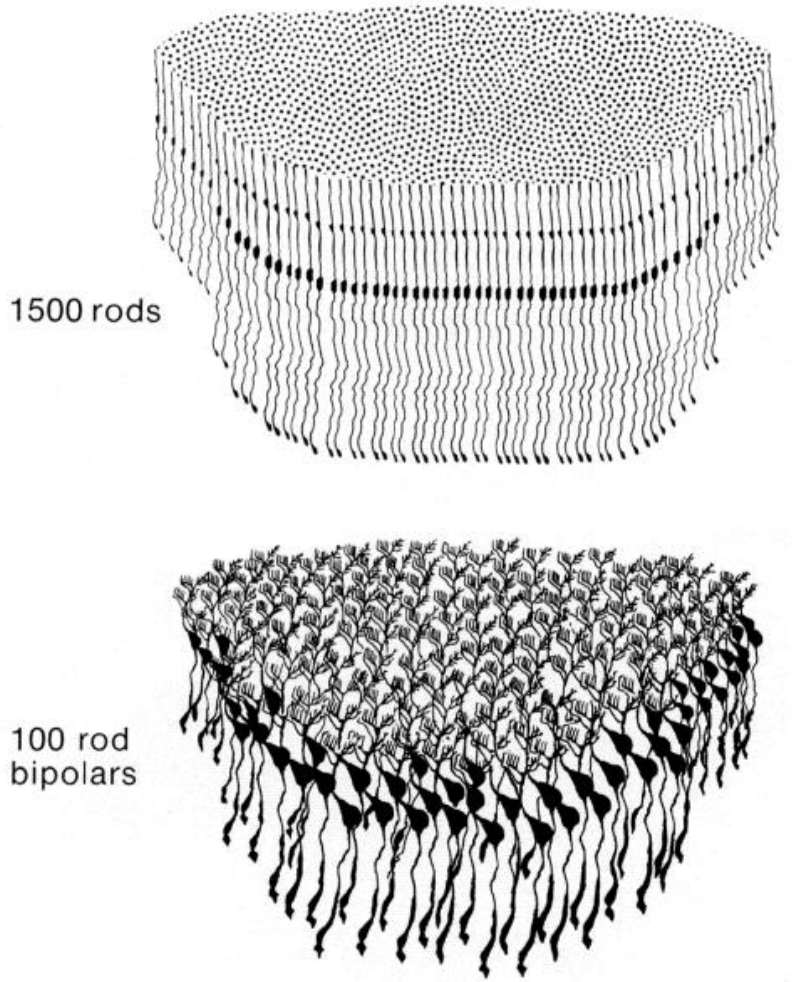

5 AII amacrines

$4 \mathrm{CBb}_{1}$ cone

bipolar axons

1 On-beta
ganglion cell
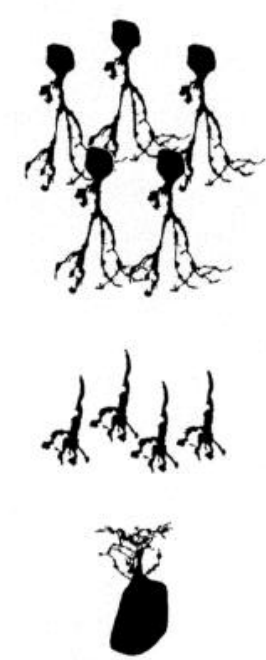

\section{Divergence}

1 rod

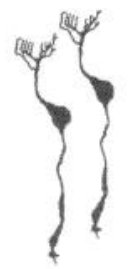

2 rod

bipolars

\section{All amacrines}

$8 \mathrm{CBb}_{1}$ cone

bipolar axons

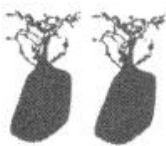

2 On-beta ganglion cells

Figure 3. Schematic diagram of the rod bipolar circuit. In this diagram, the ratio between 2 stages (e.g., 15:1 for rods and rod bipolars) differs from the estimated actual convergence (e.g., 22 rods onto one rod bipolar) because many connections between the 2 stages are shared (see text). Functional architecture treated in the Discussion.

left half of the series were identified. They were recognized by their pale cytoplasm, claw-like arborization in sublamina $b$, and large gap junctions with the AII amacrine processes (McGuire et al., 1984; Cohen and Sterling, 1986). There were 10 axons with a mean nearest-neighbor distance of $12.3 \pm 1.8 \mu \mathrm{m}$ and a density of $6500 / \mathrm{mm}^{2}$ (Fig. 4). Four of these axons had been previously reconstructed (McGuire et al., 1984). Their average tangential spread was $16 \mu \mathrm{m}$ (Fig. 5); the coverage factor was 1.3 .
The dendritic arborization of one of these cells had been previously reconstructed (Fig. 8; McGuire et al., 1984) and found to have 4 dendrites. These were observed in the tangential plane (Fig. 5) to spread $15 \mu \mathrm{m}$. This reconstruction had been thought to be incomplete; therefore, we turned to a different series (prepared by E. Cohen) to check this point. This series was also radial, 279 sections long, and at a similar eccentricity. The dendritic arborizations of $2 \mathrm{CBb}_{1} \mathrm{~s}$ were reconstructed in this material and found to have tangential spreads of $13 \mu \mathrm{m}$ diameter 
Rod

spherules

$\left(450 \times 10^{3} / \mathrm{mm}^{2}\right)$

Cone

pedicles

$\left(27 \times 10^{3} / \mathrm{mm}^{2}\right)$

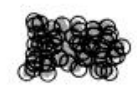

]$_{189}^{1}$

]$_{189}^{1}$

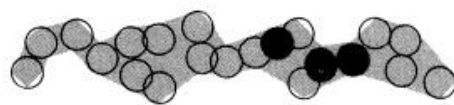

Rod bipolar

axons

$\left(30 \times 10^{3} / \mathrm{mm}^{2}\right)$

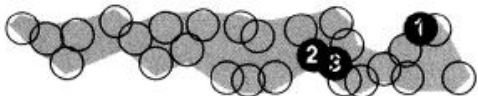

]$_{189}^{1}$

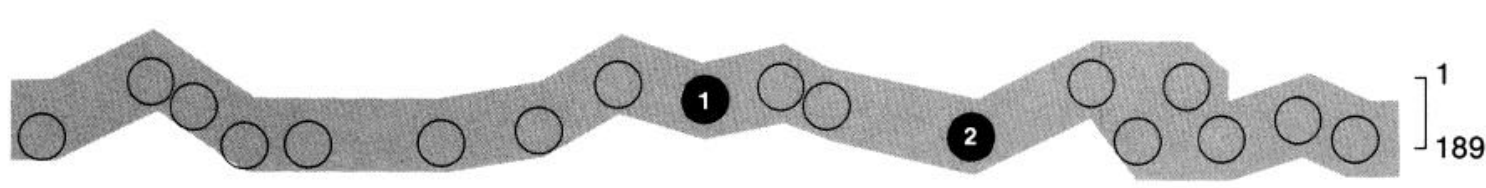

AII amacrine

somas

$\left(4.1 \times 10^{3} / \mathrm{mm}^{2}\right)$

$\mathrm{CBb}_{1}$ cone

bipolar axons

$\left(6.5 \times 10^{3} / \mathrm{mm}^{2}\right)$

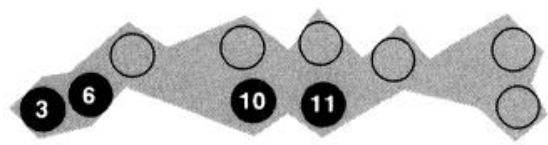

]$_{189}^{1}$

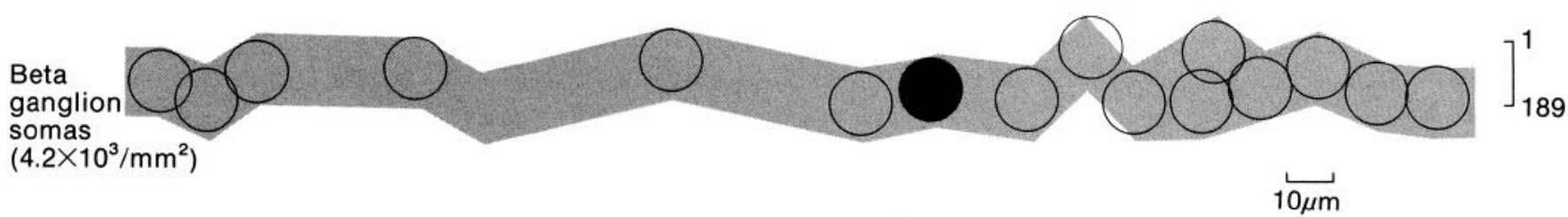

Figure 4. Density and spacing in tangential view of 6 cell types in the same patch of area centralis of one retina. The darkly shaded cells were reconstructed in detail. Numbered cells are referred to in the text. Brackets indicate the width of the region studied (189 radially oriented sections). Shaded regions indicate areas used to calculate densities (see text).

(E. Cohen and P. Sterling, unpublished observations). This convinced us that our measurement of $15 \mu \mathrm{m}$ for the diameter of the $\mathrm{CBb}_{1}$ dendritic arborization in the present series was accurate; the dendritic coverage factor was thus 1.2 , about the same as for the axon.

On-beta ganglion cells. All of the beta ganglion cells in the full patch of retina were identified. There were 17 cells recognized by their pyriform somas of medium size $(15-22 \mu \mathrm{m}$ diameter) and by their stout, proximal dendrites (Boycott and Wässle, 1974; Famiglietti and Kolb, 1976; Stevens et al., 1980b). The beta cells were distributed in the right half of the patch fairly regularly with a mean nearest-neighbor distance of 14.7 $\pm 1.9 \mu \mathrm{m}$ and a density of $4200 / \mathrm{mm}^{2}$ and in the left half of the patch somehat less regularly and at a lower density (Fig. 4). The irregularity and sparseness were attributable to a blood vessel that meandered through the array at this point, displacing cells, and we have therefore taken the figure for the right half as representative. Six of the cells were recognized as on-beta by their arborizations in sublamina $b$ and 5 were recognized as offbeta by their arborization in sublamina $a$ (Nelson et al., 1978; Wässle et al., 1981; Saito, 1983; Fukuda et al., 1984; Stanford and Sherman, 1984), but the rest of the cells could not be classified as on or off because too little of their arborizations were present in the series. It is known, however, that on-beta cells are about $48 \%$ of the total (Wässle et al., 1981). Therefore, the density of on-beta cells in this patch was probably about 2000/ $\mathrm{mm}^{2}$. The dendritic arbor of an on-beta cell at the center of the patch had been reconstructed previously (McGuire et al., 1986) and estimated to have a tangential spread of about $35 \mu \mathrm{m}$ (Fig. 5). The coverage factor was 1.9.

Horizontal cells. Horizontal cells (types A and B) are laterally connecting elements in cat retina (e.g., Kolb, 1974; Boycott et al., 1978) and thus not interposed directly along either the cone bipolar or the rod bipolar pathways. However, in trying to account structurally for the $\mathrm{CBb}_{1}$ receptive field (see Discussion), we came to consider the possible contribution of horizontal cells and therefore returned to the series to determine their distribution. The type A cells, recognized by their stout, filamentpacked dendrites and indented nuclei (Kolb, 1977), were present with a nearest-neighbor distance of $41 \mu \mathrm{m}$. Type B cells, recognized by their finer dendrites and round, unindented nuclei (Kolb, 1977), were present with a nearest-neighbor distance of $27 \mu \mathrm{m}$.

\section{Array structure: correspondence to previous studies}

The distribution densities, tangential spreads, and coverage factors of each of the cell types described here are in general agreement with earlier findings, espcially where the eccentricities of the tissue samples are closely matched. Thus, the present figures of 450,000 rods $/ \mathrm{mm}^{2}$ and 27,000 cones $/ \mathrm{mm}^{2}$ near the center of 
Rod bipolar dendrites

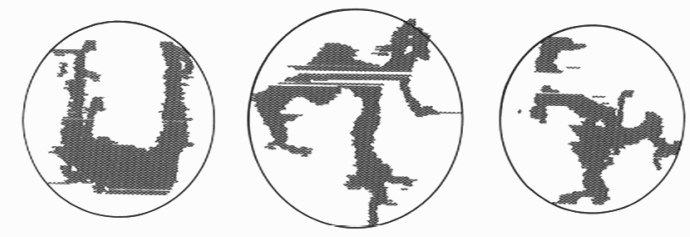

$0.96 \mu \mathrm{m}$

Rod bipolar axons

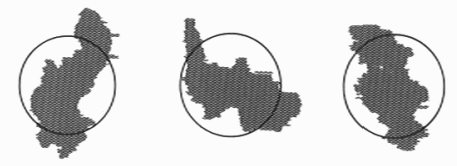

$12 \mu \mathrm{m}$

$6 \mu \mathrm{m}$

AII

amacrines
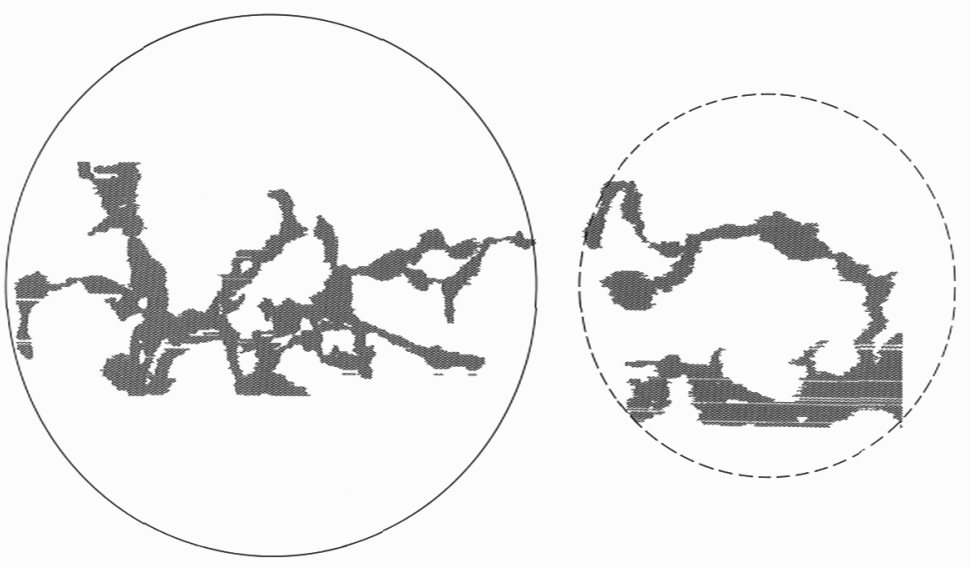

$\mathrm{CBb}_{1}$

axons
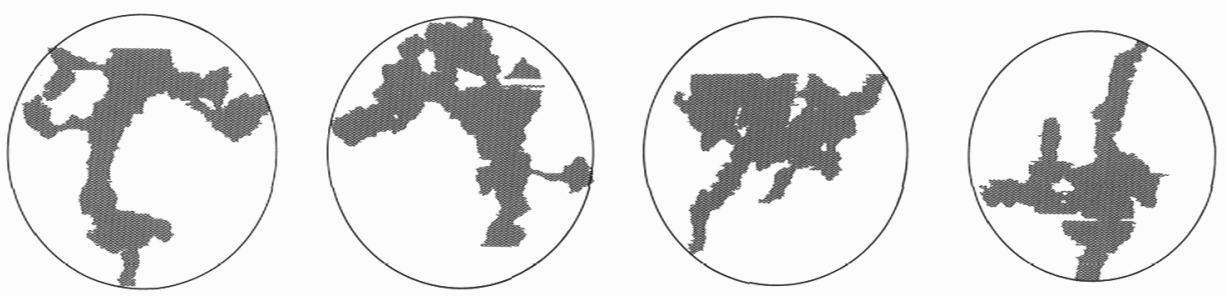

$16 \mu \mathrm{m}$

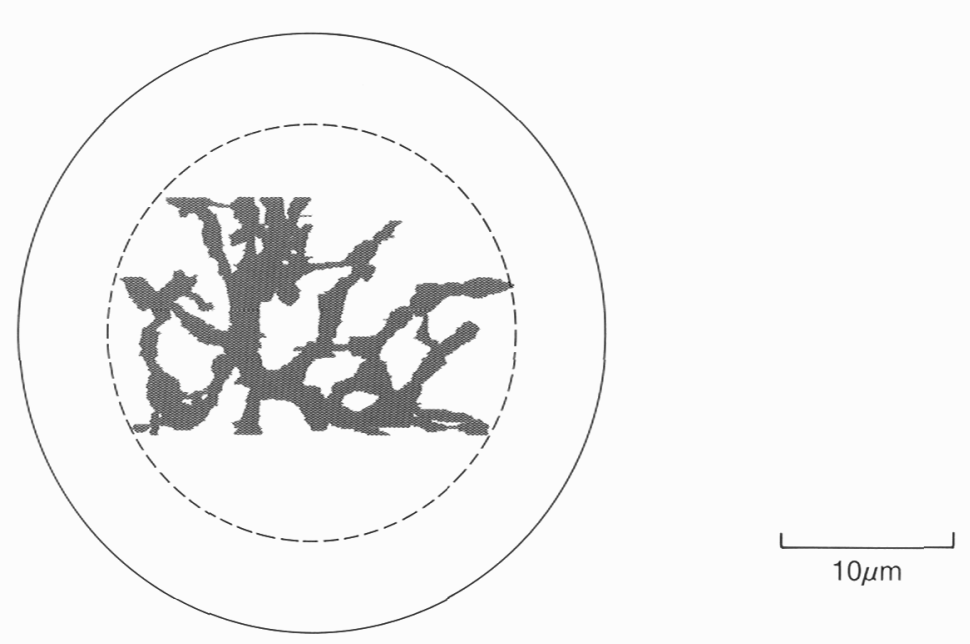

$32 \mu \mathrm{m}$

$35 \mu \mathrm{m}$

On-beta

dendrites

Figure 5. Reconstructions of the axonal and dendritic arborizations of the various cell types rotated to indicate their spreads in the tangential plane (solid circles). Dotted circles indicate that the actual spread of processes is underestimated by the reconstruction. 
Cone pedicles
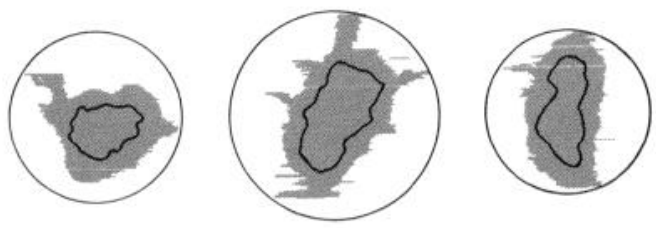

Estimated tangential spread (diameter)

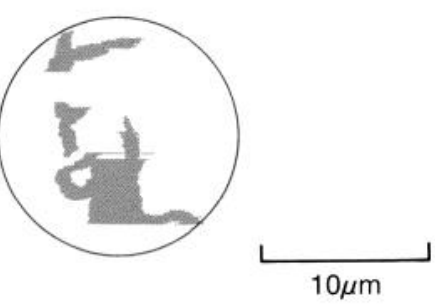

$15 \mu \mathrm{m}$

Figure 5. Continued.

the area centralis agree with the measurements of Steinberg et al. (1973); Holländer and Stone (1972); Wässle and Riemann (1978); and Smith et al. (1986). The present figure of 4100 AII amacrines $/ \mathrm{mm}^{2}$ and a coverage factor of 3.3 agrees with the measurements of Vaney (1985). Our measurement of 4200 beta cells $/ \mathrm{mm}^{2}$ is the first one available for the area centralis (cf. Wässle et al., 1981), but it is in agreement with the unpublished observations of Cohen and Sterling in a different retina at a similar eccentricity. The horizontal cell spacings agree with the measurements of Wässle et al. (1978b). The present measurement of 30,000 rod bipolars $/ \mathrm{mm}^{2}$ and $6500 \mathrm{CBb}_{1} \mathrm{~s} / \mathrm{mm}^{2}$ are similar to the observations of Cohen and Sterling in the tissue just noted.

\section{Potential connections between successive arrays}

Given the information regarding the structure of successive arrays, we wished to calculate in a standard manner how many presynaptic cells of a given type could possibly converge on a postsynaptic cell of a given type and, conversely, the number of postsynaptic cells to which one presynaptic cell could possibly diverge. Our method assumes circular fields for both pre- and postsynaptic cells (Wässle and Riemann, 1978) and that a synaptic contact can be established at any point where the circular fields of a presynaptic and a postsynaptic cell either overlap or abut. Under these assumptions, a circle whose radius is the sum of the radii of the pre- and postsynaptic fields would include all of the cells of both types that are within each other's reach (Fig. 8 ). The area of this circle times the density of the presynaptic cells gives the potential convergence between the 2 arrays; the area of the same circle times the density of the postsynaptic cell gives the potential divergence.

These calculations are presented below and in Figure 8 and summarized in Table 1. They were instructive in (1) defining an upper bound to the connectivity between pairs of arrays; (2)

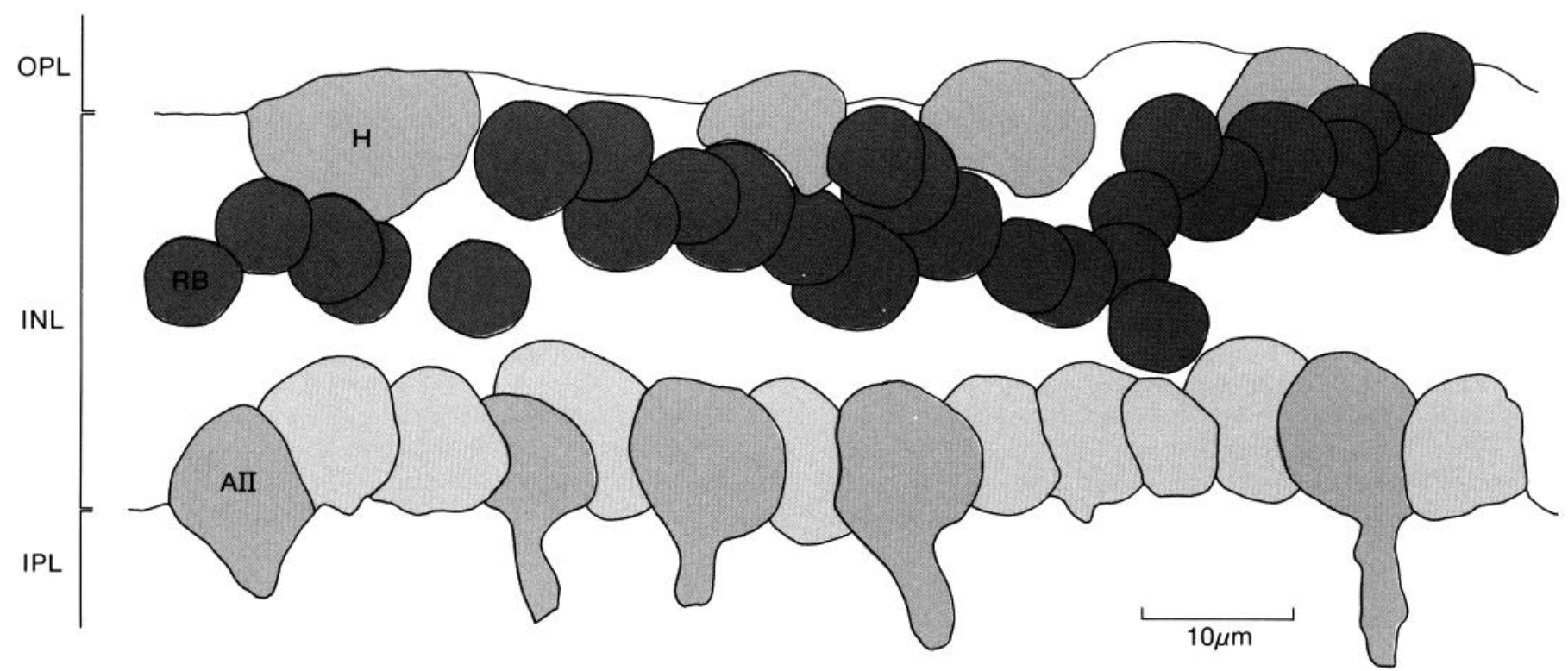

Figure 6. Radial view of the series indicating positions of all the rod bipolar cell bodies. The positions of some AII and horizontal cells $(H)$ are also indicated. $O P L$, outer plexiform layer; $I N L$, inner nuclear layer; $I P L$, inner plexiform layer. 


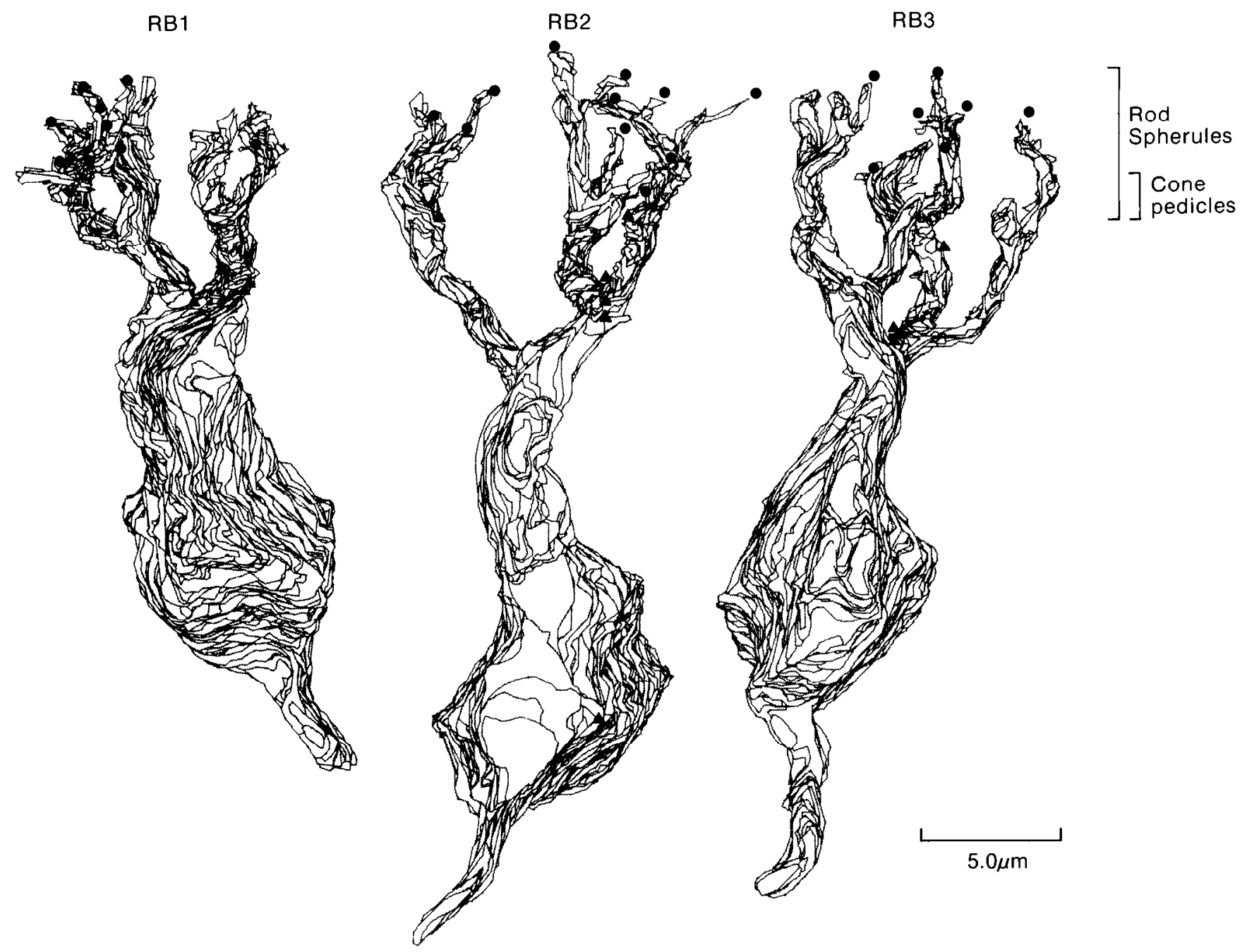

Figure 7. Dendritic arbors of 3 reconstructed rod bipolars in radial view (dot, rod synapse; triangle, interplexiform synapse). Brackets indicate laminar positions of rod and cone axon terminals.

in revealing, when compared to the actual connections, the cxtent to which the potential for contact is realized and whether the rules are the same for all pairs of arrays; and (3) in pointing out that certain fields, such as those of the AII and the beta cell, are reasonably described by a circle while others, such as the $\mathrm{CBb}_{1}$ dendritic and axonal fields, are not.

Cones to $C B b_{1}$ cone bipolars (Fig. $8 \mathrm{C}$ ). A cone pedicle provides ribbon contacts over a circular field in the tangential plane of about $2.2 \mu \mathrm{m}$ radius and the $\mathrm{CBb}_{1}$ dendrites spread tangentially within a field of $7.5 \mu \mathrm{m}$ radius. Thus, the joint radius is $9.7 \mu \mathrm{m}$. Given the densities of each type $\left(27 \times 10^{3} / \mathrm{mm}^{2}\right.$ for cones; 6.5 $\times 10^{3} / \mathrm{mm}^{2}$ for $\mathrm{CBb}_{1}$ ) and the method described above, the potential divergence is 1.9 and the potential convergence is 8 . In this case, it was obvious, however, that the $\mathrm{CBb}_{1}$ dendritic tree is not circularly symmetrical, even though we believe it to be essentially complete (see above). Therefore, the potential connections calculated by this method for this pair of arrays are not likely to be realized.

Rods to cones and rod bipolars (Fig. 8, A, B). The potential divergence of one rod to cone pedicles (by gap junctions) and to rod bipolars (by chemical synapses) is given directly by the respective coverage factors of these 2 postsynaptic elements. This is because, as noted, the site of the rod's synaptic output is essentially a point in the tangential plane; therefore, it can contact cells whose tangential spreads overlap its retinal position. One rod can potentially diverge to 2.5 cone pedicles and to 3.4 rod bipolars.

The potential convergence of rods onto a single cone pedicle is calculated as the area of a circle ( $5.5 \mu \mathrm{m}$ radius, Fig. $8 A$ ) that circumscribes the pedicle, including all its basal processes, times the rod density $\left(450 \times 10^{3} / \mathrm{mm}^{2}\right)$. The potential convergence of rods onto the rod bipolar is calculated similarly as the area of

Figure 8. Pairs of synaptically connected cell types in tangential view. In each case $(A-F)$, any presynaptic cell whose axon lies within or upon the heavy circle can potentially contact the postsynaptic cell. Therefore, the potential number of presynaptic cells converging on a postsynaptic cell can be calculated as the area of the heavy circle times the density of the presynaptic cell. Similarly, a presynaptic cell can potentially contact any postsynaptic cell that lies within or upon a circle of the same radius as the heavy circle. Therefore, the potential number of postsynaptic cells can be calculated as the area of this circle times the density of the postsynaptic cell. $R S$, rod spherule; $R B$, rod bipolar. 
A

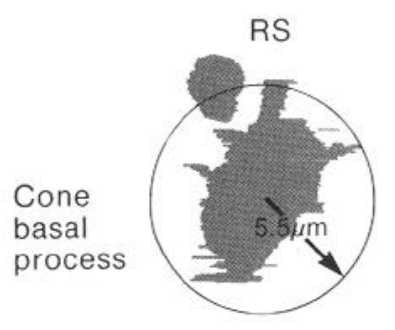

B

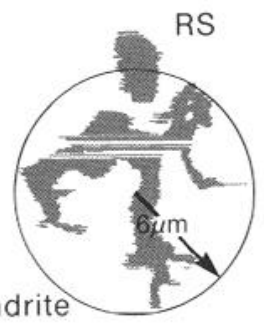

RB dendrite
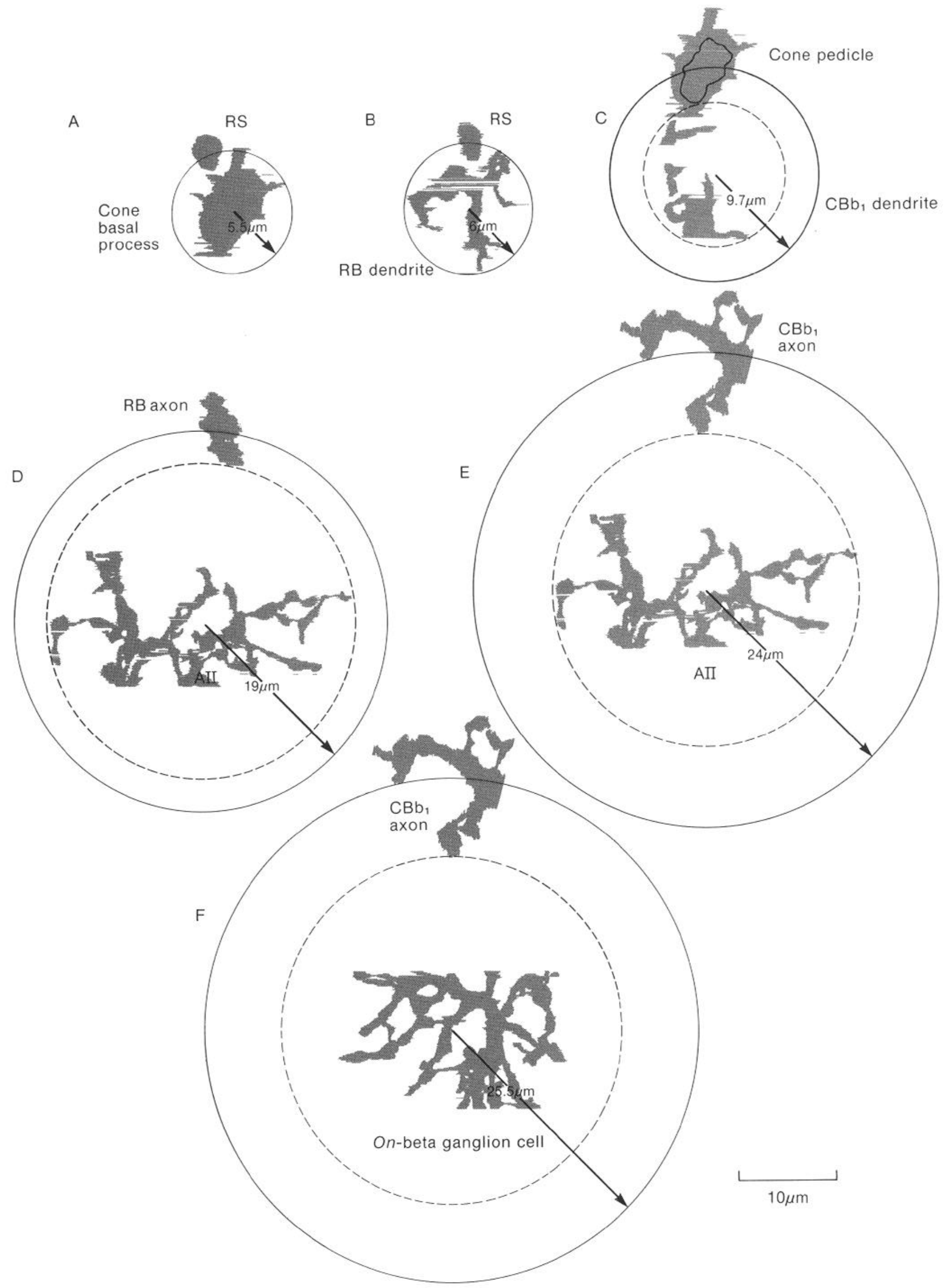

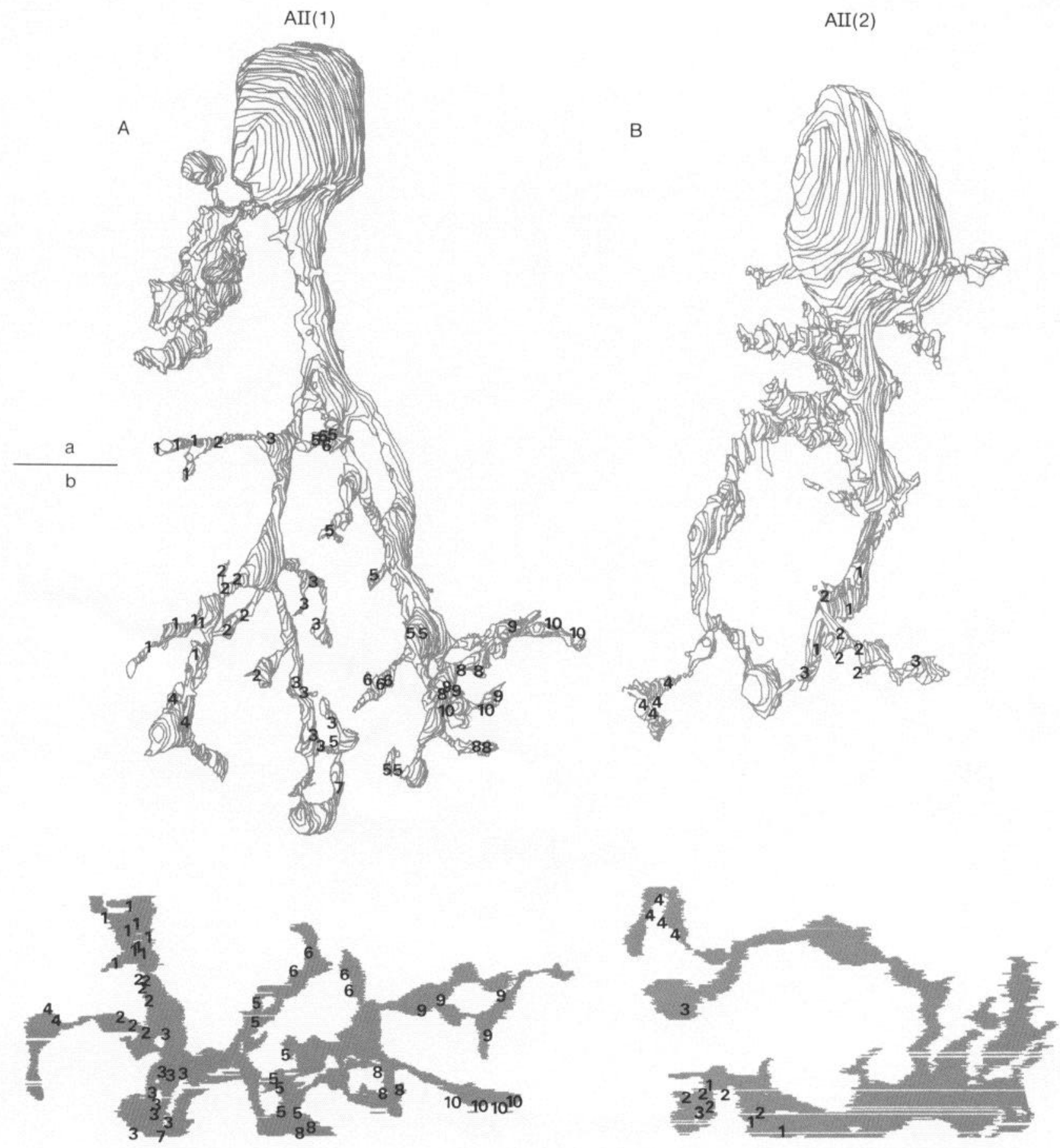

$10 \mu \mathrm{m}$

Figure 9. Two reconstructed AII amacrine cells viewed radially (above) and tangentially (below). Numbers indicate locations of synapses from individual rod bipolar axons. Note that most synapses are on tangentially oriented branches. Synapses from different rod bipolar axons do not overlap in the tangential plane. For AII (2) synapses from rod bipolar (3) appear to be widely separated and admixed with synapses from rod bipolars (1) and (2). This is an illusion created by the particular rotation presented here and not a violation of the rule. 
a circle $(6 \mu \mathrm{m}$ radius, Fig. $8 B)$ that circumscribes the rod bipolar dendritic tree times the rod density. Potentially, 43 rods converge on one cone pedicle and 51 rods converge on one rod bipolar cell.

Rod bipolars to AII amacrines (Fig. 8D). The output sites of the rod bipolar axon occupy, not a point in the tangential plane, but rather an ellipse averaging $3.5 \mu \mathrm{m}$ radius. A circle about the AII dendritic field is $15.5 \mu \mathrm{m}$, which gives a joint radius of 19 $\mu \mathrm{m}$. The potential divergence calculated from the arca of the joint circle times the AII density $\left(4.1 \times 10^{3} / \mathrm{mm}^{2}\right)$ is 4.7 ; the potential convergence calculated as the area of the same circle times the rod bipolar density $\left(30 \times 10^{3} / \mathrm{mm}^{2}\right)$ is 34 .

AII amacrine to $C B b_{1}$ (Fig. $8 \mathrm{E}$ ). The potential divergence of the $\mathrm{AII}$ amacrine to $\mathrm{CBb}_{1}$ cone bipolar axons was calculated in a similar manner as for the rod bipolar-AII pair, from the area of a circle ( $24 \mu \mathrm{m}$ radius) that includes the AII processes overlapping the $\mathrm{CBb}_{1}$ axon and also those abutting it, times the $\mathrm{CBb_{1 }}$ density $\left(6.5 \times 10^{3} / \mathrm{mm}^{2}\right)$. This calculation indicates that one AII cell potentially diverges to $12 \mathrm{CBb}_{1}$ axons. The potential convergence of the AII to the $\mathrm{CBb}_{1}$ is calculated as the area of the same circle times the AII density $\left(4.1 \times 10^{3} / \mathrm{mm}^{2}\right)$ giving a potential convergence of 7.4 .

$C B b_{1}$ to on-beta (Fig. $8 \mathrm{~F}$ ). The potential divergence of the $\mathrm{CBb}_{1}$ axon to on-beta cells was calculated in the same manner. The radius of the circle that included the overlapping and the abutting $\mathrm{CBb}_{1}$ axons was $25.5 \mu \mathrm{m}$. The area of this circle times the on-beta cell density $\left(2.0 \times 10^{3} / \mathrm{mm}^{2}\right)$ gives a potential divergence of 4.1 . The same area times the $\mathrm{CBb}_{1}$ density $(6.5 \times$ $10^{3} / \mathrm{mm}^{2}$ ) gives a potential convergence of 13 .

\section{Actual divergence and convergence between arrays}

We identified as completely as possible the synaptic contacts between specific cells in each pair of arrays. It was usually impossible to find every contact because most cells had some processes that extended beyond the series. We therefore estimated the completeness of individual reconstructions and extrapolated to find the actual divergence and convergence between arrays. An important check on the accuracy of these procedures was provided by the equation described elsewhere (Freed et al., 1987) relating the densities of 2 arrays and their connectivity:

$$
\mathrm{A} / \mathrm{B}=\mathrm{conv} / \mathrm{div}
$$

where type $a$ is presynaptic to type $b, A$ is the density of cell $a$, $B$ is the density of cell $b$, conv is the number of cell type a presynaptic to one type $b$ (convergence), div is the number of cell type $b$ postsynaptic to one type a (divergence).

The ratio of convergence to divergence determined by extrapolation from the observed connections was always fairly close to the ratio of the densities. The latter was determined by an entirely different set of measurements (Fig. 4). Therefore, the determinations of the actual connections between arrays were considered to be fairly accurate.

Rods to cones. Twenty-three rod spherules were traced completely through serial sections. Two had no gap junction contacts and 21 had $1-5$ contacts per spherule. The average for all 23 was $2.5 \pm 1.4$ contacts per rod spherule. Each junction on a rod spherule is thought to arise from the basal process of a different cone pedicle (Smith et al., 1986); therefore, each rod spherule diverged to 2.5 cone pedicles.

The reconstructed cone pedicles were observed to receive only a few rod spherule gap junctions on their basal processes. Ad-
Table 1. Estimated connections (potential and actual) for rod and cone circuits to on-beta cell

\begin{tabular}{|c|c|c|c|c|}
\hline & \multicolumn{2}{|l|}{ Potential } & \multicolumn{2}{|l|}{ Actual } \\
\hline & $\begin{array}{l}\text { Conver- } \\
\text { gence }\end{array}$ & $\begin{array}{l}\text { Diver- } \\
\text { gence }\end{array}$ & $\begin{array}{l}\text { Conver- } \\
\text { gence }\end{array}$ & $\begin{array}{l}\text { Diver- } \\
\text { gence }\end{array}$ \\
\hline Rod $\rightarrow$ cone & 43 & 2.5 & $42^{a}$ & 2.5 \\
\hline Rod $\rightarrow$ rod bipolar & 51 & 3.3 & 22 & 1.9 \\
\hline $\begin{array}{l}\text { Rod bipolar } \rightarrow \text { AlI } \\
\text { amacrine }\end{array}$ & 34 & 4.7 & 28 & 4.2 \\
\hline Cone $\rightarrow \mathrm{CBb}_{1}$ & 8.0 & 1.9 & 4 & 1.0 \\
\hline $\mathrm{AII} \rightarrow \mathrm{CBb}_{1}$ & 7.4 & 12 & 1.3 & 1.5 \\
\hline $\mathrm{CBb}_{1} \rightarrow$ on-beta & 13 & 4.1 & 4 & 1.3 \\
\hline
\end{tabular}

astimated from equation (1).

ditional junctions were observed on basal processes in the surrounding neuropil but could not be traced to a particular cone pedicle. In this case, the actual convergence of rods onto cones could not be determined directly and had to be derived from equation (1):

$$
\underset{\text { of rods }}{\text { convergence }}=\frac{(\text { rod density)(actual divergence of rods) }}{\text { cone density }}
$$

The actual convergence of rods onto cones was thus estimated to be 42 . These results are in agreement with more extensive measurements from a series of tangential sections at about the same eccentricity (Smith et al., 1986).

Cones to $C B b$, bipolars. The convergence of cones onto the $\mathrm{CBb}_{1}$ was studied in one case from the present series (cell 11 , Fig. 4) which had been reconstructed previously and shown in radial view (McGuire et al., 1984; Fig. 8). Nine other $\mathrm{CBb}_{1} \mathrm{~s}$ had been identified in this series (Fig. 4) by their axonal arborizations, but their dendritic trees had been cut away because the series was tilted slightly with respect to the bipolars' vertical axis. Therefore, we studied the 2 additional $\mathrm{CBb}_{1}$ dendritic arbors that, as noted, had been reconstructed from a different series at a similar eccentricity $(<0.5 \mathrm{~mm}$ from the center of the area centralis). These cells will be illustrated as part of a different study (E. Cohen and P. Sterling, unpublished observations). The results for all 3 cells were the same.

Each cell emitted 4 dendrites that ascended to the outer plexiform layer. The dendrites were followed to their terminations in $11 / 12$ cases. They spread narrowly $(13-15 \mu \mathrm{m})$ in the tangential plane, and each dendrite terminated in a cluster of fine branchlets subjacent to a single cone pedicle. The branchlets invaginated the pcdiclc and in some cases were traced to "semiinvaginating" contacts at the synaptic ribbon (Nelson and Kolb, 1983; Cohen and Sterling, 1987). Thus, each of the 11 dendrites that was followed to its termination received multiple contacts from a single cone. Assuming that the 12 th dendrite terminated similarly, there would be 4 cones converging on each $\mathrm{CBb}_{1}$. The cones converging on a given $C B b_{1}$ were immediate neighbors; that is, no cones were interposed that did not contact that bipolar.

These observations can be compared to previous studies because the type $\mathrm{CBb}_{1}$ defined by McGuire et al. (1984) corresponds in morphology and connectivity to the type called CB5 by Kolb et al. (1981) and Nelson and Kolb (1983); CB5, in turn, is considered by these authors (Kolb et al., 1981) to correspond 
to the "invaginating" cone bipolar described by Boycott and Kolb (1973).

There is fairly good agreement between all these studies. The minimum number of terminal clusters (and thus the minimum number of converging cones) observed by Boycott and Kolb on the invaginating bipolar was $4-5$, and they believed the cells with the fewest clusters to lie in the central area. The Golgiimpregnated CB5 cells illustrated in Figures 1 and 2 of Kolb et al. (1981) both have 4-5 clusters of terminals on their main dendrites plus a few single terminals arising from very fine secondary processes. These cells, which were respectively 3 and 7 $\mathrm{mm}$ eccentric to the area centralis, probably collected multiple contacts from each of 4-5 cones and a few contacts from 1-2 additional cones.

The dendritic spread of these CB5 cells (Kolb et al., 1981) appears to be about $18-22 \mu \mathrm{m}$. This span is only a little greater than the 13-15 $\mu \mathrm{m}$ observed from our reconstructions, and it is in an expected direction. Because the mean distance between neighboring cones increases with increasing eccentricity, the cone bipolar dendritic span would have to increase to reach the same number of cones. For example, at $3 \mathrm{~mm}$ eccentricity, the mean nearest-neighbor distance for cones is $7.8 \mu \mathrm{m}$ (Wässle and Riemann, 1978), while at less than $0.5 \mathrm{~mm}$ eccentricity, it was 5.8 $\mu \mathrm{m}$ (present material). Thus, to reach 4-5 neighboring cone pedicles at $3 \mathrm{~mm}$ eccentricity would require a dendritic span of 18-20 $\mu \mathrm{m}$ (Fig. 2; Kolb et al., 1981), but to reach the same number of cones at less than $0.5 \mathrm{~mm}$ eccentricity would require a dendritic span of no more than $15 \mu \mathrm{m}$. The general statement by Kolb et al. (1981) that the dendritic field of CB5 is " $30-50$ $\mu \mathrm{m}$ in all areas" may well be correct for large expanses of retina where the mean distance between neighboring cones is fairly constant, but it does not apparently describe cells in the area centralis studied here and by Boycott and Kolb (1973) nor those at slightly greater eccentricities $(3,7 \mathrm{~mm})$ illustrated by Kolb et al. (1981).

The number of $\mathrm{CBb}_{1} \mathrm{~s}$ to which one cone diverges could not be determined directly by reconstruction because one could never be certain that all of the fine processes entering a cone pedicle had becn identificd. However, the divergence can be derived from equation (1). Given the ratio of cone/CBb cell densities (4.2) and the convergence of 4 , the divergence must be very close to one. This agrees with the conclusions of Boycott and Kolb (1973) and also with our unpublished observations (E. Cohen and P. Sterling).

Rods to rod bipolars. All 25 rod spherules studied in detail had at least one synaptic ribbon marking a chemical synapse onto a rod bipolar dendrite. Most spherules (23) had 2 ribbons and none had more than 2 . The mean and SD was $1.9 \pm 0.3$. Usually the 2 ribbons of a spherule contacted dendrites of different rod bipolar neurons, but in 3 cases they contacted the same rod bipolar. Thus, the actual divergence of rods to rod bipolars was slightly less than it would have been if each ribbon in a spherule was directed at a different rod bipolar. The actual divergence (mean plus SD) was calculated to be $1.9 \pm 0.3$.

The dendritic arborizations of 3 rod bipolar cells were reconstructed, and their synaptic contacts were identified (Fig. 7). Each cell had a stout primary dendrite that divided into $2 \mathrm{sec}$ ondary dendrites, and each of these formed a pair of tertiary dendrites. Most of these continued to divide, forming a complex, candelabra-like arbor with branches up to the seventh order. We were impressed that even with repeated subdivision the dendritic branches remained fairly thick until they terminated in the fine thorns that invaginate the rod spherules. Such thorns were found on some of the third order dendrites, on half of the fourth order, and on about two-thirds of the fifth order dendrites (Fig. 7). One cell (RB1) had 18 thorns, another (RB2) had 15, and the third $(\mathrm{RB} 3)$ had 12 . In each case more than half of the thorns could be traced to the invagination of a rod spherule. Some thorns could not be traced to a spherule. We believe that this was for technical reasons and that every thorn probably did receive a contact (see Boycott and Kolb, 1973). On RB2 and RB3 each contact was from a different rod spherule, but on RB1, 3 of the 7 spherules made 2 contacts apiece.

None of the 3 rod bipolar dendritic trees were reconstructed completely because some of the finest branches could not be followed to their terminations. We estimated the degree of completeness for the 3 cells at 73\%, (RB1), 64\% (RB2), and 60\% (RB3). Thus, the complete cells would probably have, respectively, 25, 24, and 20 thorns and thus convergence from a corresponding number of rod spherules, less the 3 rod spherules that contact the RB1 twice. Thus, the average number of rods actually converging on a rod bipolar cell in this tissue was calculated to be 22 . The ratio of convergence/divergence was 11.6 , which is reasonably close to the ratio of the densities, 15, as it should be according to equation (1).

Synaptic contacts on proximal rod bipolar dendrites. Chemical synaptic contacts were observed proximally on each of the reconstructed rod bipolar neurons (Fig. 7). The presynaptic elements had pale cytoplasm with numerous synaptic vesicles, and the sites of contact often had a fine density between the preand postsynaptic elements. These synapses are almost certainly from GABA-ergic interplexiform cells (Kolb and West, 1977; Nakamura et al., 1980). The present reconstructions indicate that most of the interplexiform cell synapses are located on the first- to third-order dendrites. In this location the reconstructions were largely complete; therefore, each rod bipolar dendritic tree bears 4-5 interplexiform cell synapses. Freed et al. (1987) showed that the axon of each rod bipolar also receives 2-3 synapses that are probably from the interplexiform cell. Whether the dendritic and axonal synapses are from the same interplexiform cell is unknown. The $\mathrm{CBb}_{1}$ dendrites also receive interplexiform input (McGuire et al., 1984).

Divergence of rod bipolars on All amacrine cells. The divergence of the rod bipolar to AII amacrines was determined in 2 ways. The first method was to determine the total number of contacts made by a rod bipolar onto AII processes and divide by the average number of contacts made onto one AII cell by a single rod bipolar. Three reconstructed rod bipolar axons provided respectively 17,27 , and 25 contacts to AII processes, for an average of 23 (Table III, McGuire et al., 1984). The average number of contacts provided to one AlI by a single rod bipolar was determined by reconstructing an AII cell and finding all the rod bipolar contacts. There were 56 contacts, located mostly on the tangentially oriented processes (Fig. $9 A$ ). Next, we identified the origins of these contacts by tracing them to the stalks of the rod bipolar axons descending through the AII arbor. There were 9 such axons, and every one of these provided contacts to the reconstructed AII cell (Fig. 9, $A$ and $B$ ). Three rod bipolar axons each provided 9 contacts; 5 others provided $4-7$ contacts, and 1 rod bipolar axon, at the margin of the AII arbor, provided 2 contacts. A tenth rod bipolar axon whose stalk lay just beyond the margin of the AIl arbor provided a single contact (Fig. $9 \mathrm{~A}$, no. 7). Thus, a single rod bipolar provided a maximum of 9 and an avcragc of 5.6 contacts to this single AII amacrine. The 
divergence estimated by this method was $23 / 5.6$, or 4.1 AII cells contacted by a single rod bipolar.

The second method was to identify all the AII processes postsynaptic to a single rod bipolar axon and trace them through the series to determine whether they belonged to the same or a different AII cell. This procedure was performed in a different scrics, also from the area centralis (Freed et al., 1987). The result of this procedure, applied to 21 AII processes postsynaptic to 5 rod bipolar axons was 4.2 AII cells contacted by a single rod bipolar, which is virtually the same as determined by the first method.

Convergence of rod bipolar to AII. The partially reconstructed AII cell was determined from the tangential view (Fig. 9A) to be about $36 \%$ complete. Since this reconstructed portion received 56 contacts from 10 rod bipolars, the complete cell was estimated to have 156 contacts contributed by the convergence of 28 rod bipolar axons. The ratio of convergence/divergence was $28 / 4.1=6.8$, and this was rather close to the ratio of the densities (7.4), as it should be according to equation (1). The contacts from an individual rod bipolar were clustered in the tangential plane and not interlaced with those from other rod bipolars (Fig. 9).

Divergence and convergence of $A I I$ cells to $C B b$, axons. The synaptic output of the AII amacrine cell in sublamina $b$ of the inner plexiform layer is achieved by gap junctions with the cone bipolar axons (Famiglietti and Kolb, 1975; McGuire et al., 1984; Cohen and Sterling, 1986). We determined the divergence of the AII to $\mathrm{CBb}_{1}$ axons by identifying all the gap junctions on 2 reconstructed AII cells and tracing the postsynaptic processes back to their parent structures in sublamina $b$, which were all cone bipolar axons. One AII cell (Fig. 10A) had 9 gap junctions in sublamina $b$. These, when individually reconstructed (Fig. $10 C$ ), were observed to be disk shaped and to range in size from 0.1 to $0.99 \mu \mathrm{m}^{2}$. Six were to $\mathrm{CBb}_{1}$ axons. There were 4 junctions totaling $1.4 \mu \mathrm{m}^{2}$ to one $\mathrm{CBb}_{1}$ and 2 junctions totaling $1.2 \mu \mathrm{m}^{2}$ to a second $\mathrm{CBb}_{1}$. Of the remaining 3 junctions, one $\left(0.32 \mu \mathrm{m}^{2}\right)$ was with a type $\mathrm{CBb}_{2}$ cone bipolar (McGuire et al., 1984), and 2 (totaling $0.27 \mu \mathrm{m}^{2}$ ) were with cone bipolar axons that contained dark cytoplasm but were unidentified as to type.

A second reconstructed AII cell (Fig. 10, $B$ and $C$ ) had 11 gap junctions totaling $4.39 \mu \mathrm{m}^{2}$. Seven of these $\left(3.57 \mu \mathrm{m}^{2}\right)$ were to a single $\mathrm{CBb}_{1}$ axon. Three $\left(0.7 \mu \mathrm{m}^{2}\right)$ were to $\mathrm{CBb}_{2}$ axons, and one $\left(0.12 \mu \mathrm{m}^{2}\right)$ was to an unidentified process. Thus, in both cases the AII cell provided multiple, large gap junctions to axon terminals of the type $\mathrm{CBb}_{1}$ cone bipolar, and in both cases the divergence was minimal-to $2 \mathrm{CBb}_{1} \mathrm{~s}$ in the first case and to 1 in the second, for an average divergence of 1.5 . In both cases also, there were smaller contacts to $\mathrm{CBb}_{2}$.

The divergence was studied in another way, by finding the average number of gap junctions provided to $\mathrm{CBb}_{1}$ axons by a single AII and dividing by the average number of junctions on a single $C B b_{1}$ axon. Four reconstructed $\mathrm{CBb}_{1}$ axons had an average of 4.8 gap junctions (McGuire et al., 1984), and the average number of $\mathrm{AII}-\mathrm{CBb}_{1}$ gap junctions from a single AII was 6.5 (Fig. 10, $A$ and $B$ ); therefore, the divergence determined by this method was 1.4 .

The convergence of AIIs onto the $\mathrm{CBb}_{1}$ was determined from the reconstructions of $3 \mathrm{CBb}_{1}$ axons. The presynaptic AII processes that provided a total of 14 gap junctions to these axons were traced far enough to determine whether they belonged to the same or a different AII. One $\mathrm{CBb}_{1}$ (cell 3) collected from 2 diffcrent AII cells and the other $\mathrm{CBb}_{1}$ s (cells 6 and 10) each collected from only a single AII. Therefore, about 1.3 AII cells converge onto a single $\mathrm{CBb}_{1}$ axon.

The foregoing determinations of actual divergence and convergence were verified by applying equation (1). It was found that the ratio of the densities $(0.63)$ was fairly close to the ratio of the convergence to the divergence (about 0.9 ). This suggests that both sets of measurements were fairly accurate.

The reconstructions of the AII cells were only partial, being $36 \%$ complete in the first case and less in the second. One may wonder, therefore, why we have not corrected the observed AII$\mathrm{CBb}_{1}$ connections for this as we did for the rod bipolar-AII connections. The correction procedure has the underlying assumption that the location of the outputs on the presynaptic cell and the inputs on the postsynaptic cell are distributed with equal probability on all parts of the arborization in the tangential plane. This was true for the outputs from the rod bipolar axon and for their inputs to the AII arbor (Fig. 9). It was also true for the gap junction inputs on the $\mathrm{CBb}_{1}$ axons. These were distributed nonselectively to the base of the axon and also to the finest peripheral branches (Fig. 11; see also Fig. 8 of McGuire et al., 1984). It was not true, however, for the gap junction outputs from the AII.

The gap junction outputs of the $\mathrm{AII}$ to the $\mathrm{CBb}_{1}$ did not arise with equal probability from all parts of the AII arborization. Figure $10 \mathrm{~A}$ shows that these junctions originated from one branch of the bifurcated central stalk of the AII and that the distribution of these outputs in the tangential plane was circumscribed by a circle $17 \mu \mathrm{m}$ in diameter. The coverage factor calculated for a circle of this diameter and the AII density was 0.93 , which is similar to what was calculated by Vaney (1985) for the chemical synaptic output of the AII's lobular appendages in sublamina $a$. The gap junction outputs to $\mathrm{CBb}$, from the second AII cell were also more circumscribed in origin than the inputs to this cell from rod bipolars (cf. Figs. $8 B$ and $10 B$ ). Although the second AII was less complete than the first, the number and total area of its gap junctions were similar to that of the first (more complete) cell, so it seems possible that most of its gap junctions were accounted for. It thus appears that the AII cell is designed to collect a widely convergent input from rod bipolars in sublamina $b$, but to provide in both sublaminae a narrowly divergent output. The possible function of this architectural feature is treated in the Discussion.

Convergence and divergence of $C B b_{l}$ to the on-beta cell. The on-beta cell whose reconstruction is shown in Figure 12 was studied previously by McGuire et al. (1986). It was shown to have multiple contacts from two types of cone bipolar, $\mathrm{CBb}_{1}$ and $\mathrm{CBb}_{2}$. We examined this cell further, plotting the distribution of contacts from a second $\mathrm{CBb}_{1}$ axon and from amacrine cells.

As is shown in Figure $12 A$, the on-beta cell received multiple contacts from two $\mathrm{CBb}_{1} \mathrm{~s}, 47$ from the first (cell 6) and 22 from the second (cell 3), as noted previously (McGuire et al., 1986). It is also shown that the distributions of the contacts from the two $\mathrm{CBb}_{1}$ s to the beta cell had essentially no overlap. This territorial segregation of contacts in the tangential planc is apparently specific to cone bipolars because, as shown in Figure $12 B$, the 108 amacrine contacts are widely distributed to the on-beta dendritic tree and are not excluded by the presence of cone bipolar contacts. The beta cell reconstruction is believed to be about $50 \%$ complete (McGuire et al., 1986), and it is likely that dendritic fields not included in the reconstruction would provide territory for contact by additional $\mathrm{CBb}_{1} \mathrm{~s}$. We therefore 

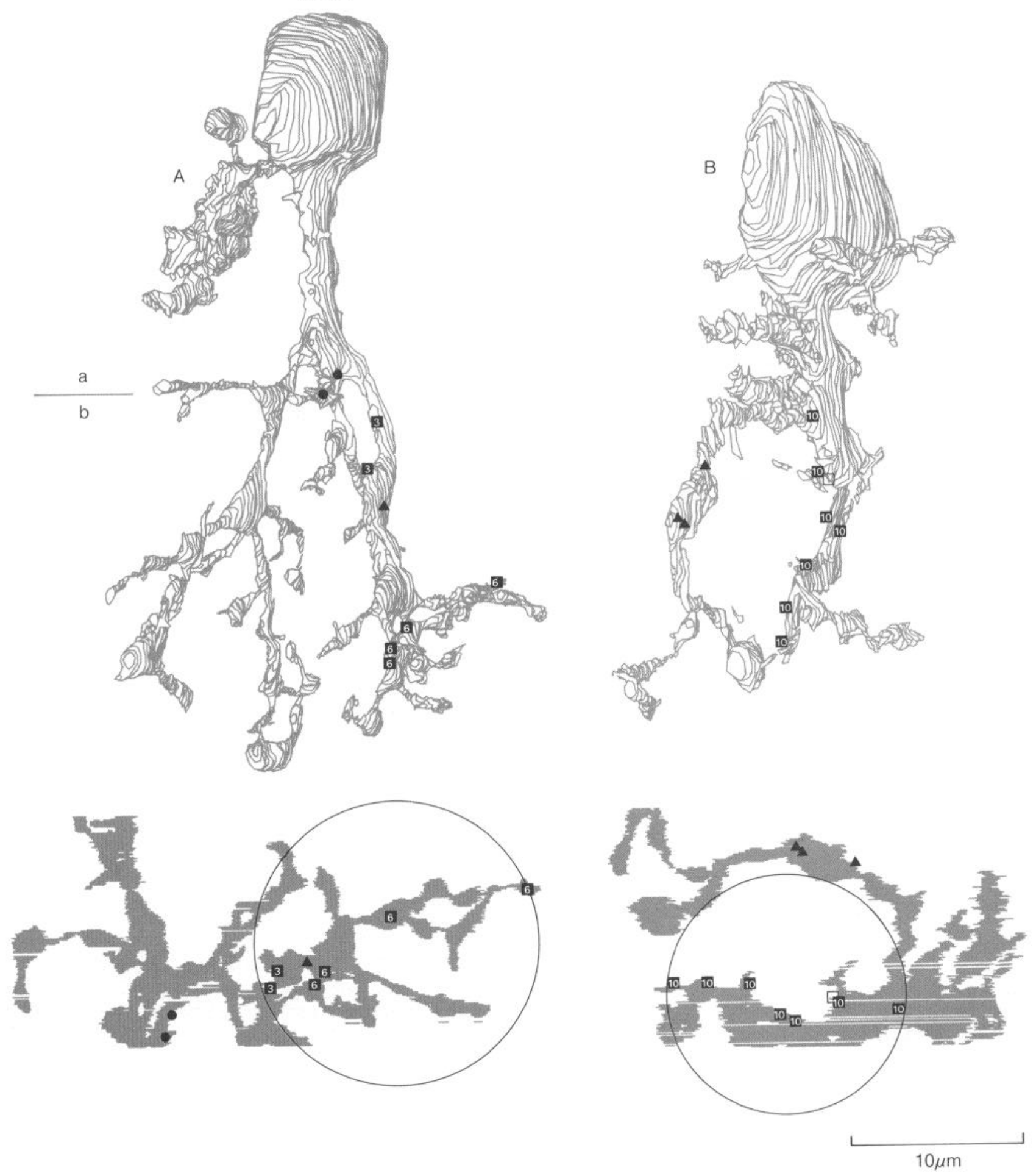

Figure 10. $A$ and B, Same AII cells as in Figure 9. Numbered squares indicate gap junctions with individual $\mathrm{CBb}_{1}$ axons. Numbers refer to cells whose tangential positions are shown in Figure 4. Triangles indicate gap junctions to $\mathrm{CBb}_{2}$ axons, and dots indicate gap junctions to unidentified processes. Note that gap junctions to $\mathrm{CBb}_{1}$ axons arise from one vertical stalk of each AII. The tangential extent of the gap junction output to $\mathrm{CBb}_{1}$ is therefore narrower than the extent of the rod bipolar input. $C$, Reconstruction of gap junctions whose locations are shown in $A$ and $B$. The junctions are roughly discoid; those to $\mathrm{CBb}$, are larger and more numerous than those to other cell types. 
Gap junction from AII

amacrine (1) to cone bipolars

$\mathrm{CBb}_{1}$

(cell 6)
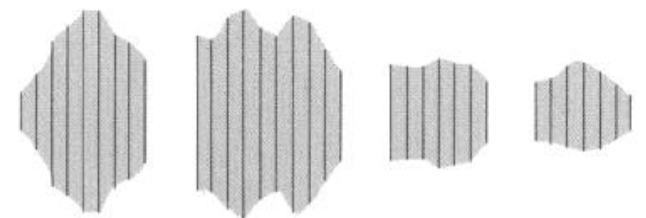

$\left(0.42 \mu \mathrm{m}^{2}\right)$

$\left(0.62 \mu \mathrm{m}^{2}\right)$

$\left(0.2 \mu \mathrm{m}^{2}\right)$

$\left(0.17 \mu \mathrm{m}^{2}\right)$

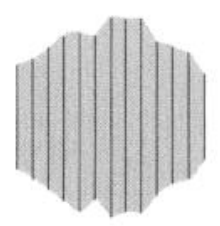

$\left(0.65 \mu \mathrm{m}^{2}\right)$

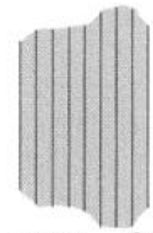

$\left(0.55 \mu \mathrm{m}^{2}\right)$

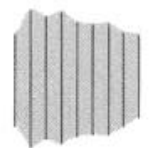

$\left(0.32 \mu \mathrm{m}^{2}\right)$

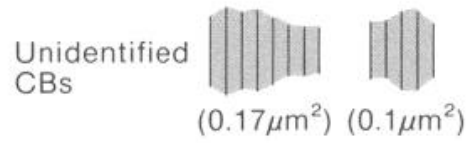

Gap junction from AII

amacrine (2) to cone bipolars
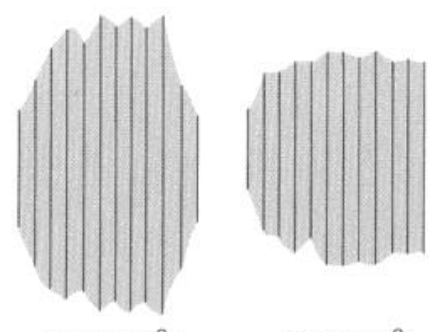

$\left(0.79 \mu \mathrm{m}^{2}\right)$

$\left(0.70 \mu \mathrm{m}^{2}\right)$

$\left(0.99 \mu \mathrm{m}^{2}\right)$

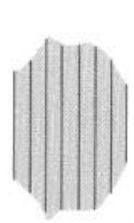

$\left(0.40 \mu \mathrm{m}^{2}\right)$
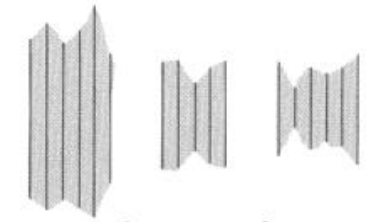

$\left(0.36 \mu \mathrm{m}^{2}\right)\left(0.17 \mu \mathrm{m}^{2}\right)\left(0.16 \mu \mathrm{m}^{2}\right)$

$\mathrm{CBb}_{2}$
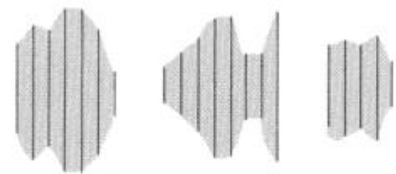

$\left(0.29 \mu \mathrm{m}^{2}\right)$

$\left(0.27 \mu \mathrm{m}^{2}\right)\left(0.14 \mu \mathrm{m}^{2}\right)$

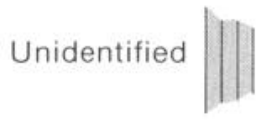

$\left(0.12 \mu \mathrm{m}^{2}\right)$

Figure 10. Continued.

estimate that at least $4 \mathrm{CBb}_{1} \mathrm{~s}$ actually converge on the on-beta cell.

The degree of divergence of the $\mathrm{CBb}_{1}$ to the on-beta cell appears to be quite limited. $A$ single $\mathrm{CBb}_{1}$ has been observed to provide many contacts to one beta cell and a few to another (McGuire et al., 1986; see also Kolb, 1979). The $4 \mathrm{CBb}_{1}$ axons reconstructed by McGuire et al. (1984) were estimated to be about $90 \%$ complete and, adjusting the number of their contacts according to their completeness, provide an average of 50 contacts apiece to dark ganglion cell dendrites-presumed beta cells (Stevens et al., 1980b). This is a minimal estimate because about $20 \%$ of the postsynaptic processes could not be identified (Table III, McGuire et al., 1984), and some of these might also be directed at beta cells. Since each of the $4 \mathrm{CBb}_{1} \mathrm{~s}$, if complete, would provide about 38 contacts to a single beta cell, then they would have enough dark ganglion cell contacts to diverge to 50/ $38=1.3$ beta cells. The divergence can also be estimated from equation (1). The ratio of $\mathrm{CBb}_{1} /$ on-beta densities is 3.25 , which according to equation (1) should equal the ratio of convergence/ divergence. The divergence should therefore equal $4 / 3.25$, or 1.2 .

\section{Rules of synaptic connection}

The synaptic connections between certain pairs of arrays follow, to a first approximation, the simple rule: "Connect to every member of the appropriate type that is within reach." Thus, the actual connections from rods to cones are identical to their potential connections, and the actual connections of rod bipolars to AII amacrine cells are close (about $80 \%$ ) to their potential connections (Table 1). The connections between other pairs of arrays do not obviously follow this rule but appear to be more restricted. Thus, less than half of the rods calculated potentially to fall within the dendritic field of a rod bipolar actually connect to it. Similarly, the AII amacrine's actual connections with the $\mathrm{CBb}_{1}$ are only about $15 \%$ of their calculated potential connections, and the $\mathrm{CBb}_{1} \mathrm{~s}$ actual connections to the on-beta are apparently only about $30 \%$ of the calculated potential connections.

Some of the discrepancies between the actual and potential connections may result from rules that restrict the subcellular sites where contacts are received or given. Thus, rod contacts are received by rod bipolars only at the dendritic tips, and these tips are restricted in number. In contrast, rod contacts are received by cones anywhere on the cone axon, pedicle, and basal processes. Similarly, electrical contacts from the AII amacrine to the $\mathrm{CBb}_{1}$ bipolar are apparently given only from certain descending branches of the AII (Fig. 10, $A, B$ ) while rod bipolar contacts are received by the AII on all descending branches (Fig. 9).

A significant part of the discrepancy between the actual and potential connections clearly results from the inaccuracy of the assumption used in calculating the potential connections, i.e., that neuronal arbors are, on the average, circular. This as- 

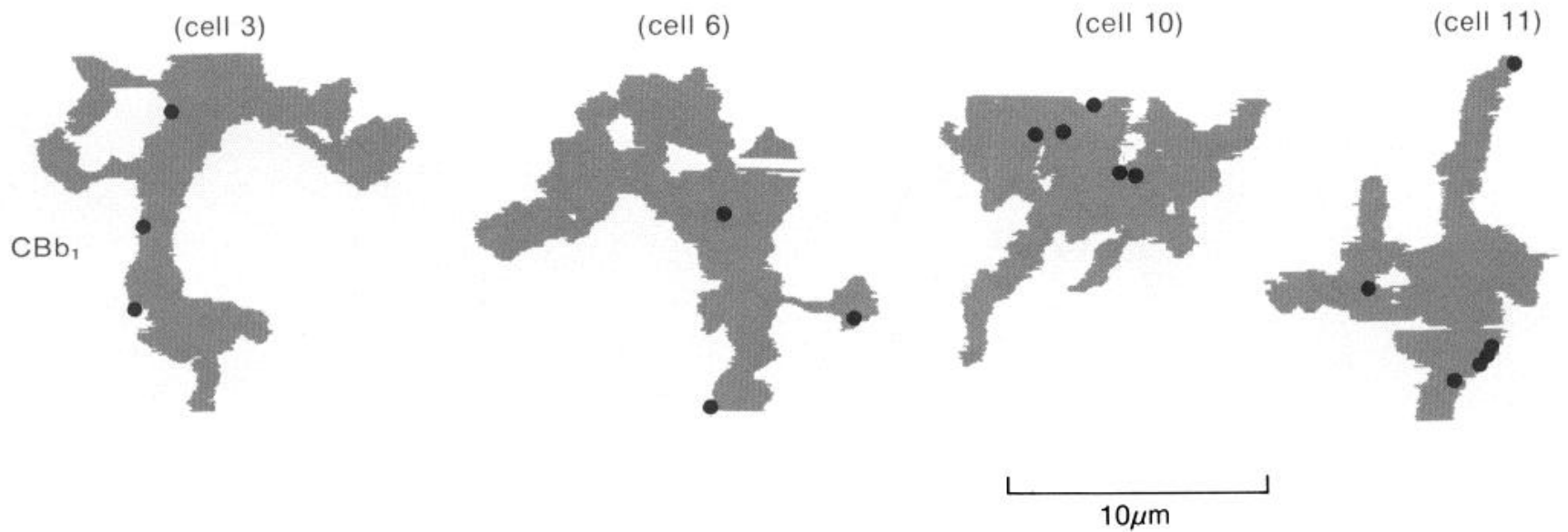

Figure 11. Reconstructed $\mathrm{CBb}_{1}$ axons in tangential view showing location of gap junctions from AII amacrine. Note that contacts are present both on the central regions of the axonal stalks and also on the distal tips of the axons. For a radial view of these axons see McGuire et al. (1984).

sumption underlies the idea of "coverage factor" (Wässle and Riemann, 1978). In certain cases this assumption proves to be reasonable; for example, the on-beta and AII dendritic arbors (where they are complete within the series) fill the territory bounded by a circle rather well (Fig. 5). In other cases, the assumption is clearly unreasonable. Thus neither the rod bipolar dendrites nor the $\mathrm{CBb}_{1}$ dendritic and axonal arbors come close to evenly filling the circles that circumscribe them in the tangential plane even though the reconstructions are nearly complete (Fig. 5). Consequently, the numbers of "potential" contacts calculated for these arbors are inflated by the assumption of a circular field. When this is taken into account, it appears that the simple rule, "contact the cells in reach" might actually hold for most pairs of arrays.

Another rule found in certain cases was that processes and contacts from different members of the same cell type do not interlace in the tangential plane. This was found for: (1) the cone- $\mathrm{CBb}$, pair in that all the cones contacting a given $\mathrm{CBb}_{1}$ were immediate neighbors; $(2)$ the $\mathrm{CBb}_{1}$-on-beta pair in that contacts from the two $\mathrm{CBb}_{1} \mathrm{~s}$ did not interlace with each other in the tangential plane (Fig. 12A) while contacts from amacrines (Fig. 12B) did interlace with $\mathrm{CBb}_{1}$ contacts; and (3) the rod bipolar-AII pair in that clustered contacts from individual rod bipolars did not interlace (Fig. 9). Apparently, the retinotopic order that is obvious and essential on the macroscopic scale, holds also (at least in the cases noted) on the microscopic scale within individual arrays.

\section{Discussion}

Schematic diagrams of the cone bipolar and rod bipolar circuits were presented early in this paper (Figs. 2, 3), and most of the Results section was devoted to presenting the data on which these diagrams are based. It must be emphasized that the diagrams are estimates reflecting the best available information; revision must be anticipated as additional data accumulate. Here we summarize the main architectural features of each circuit and then consider the possible relations to function.

\section{Architecture of the cone bipolar circuit}

Convergence in the cone bipolar circuit is narrow (Fig. 2). About 4 cones converge on a $\mathrm{CBb}_{1}$ and about $4 \mathrm{CBb}_{1}$ s converge on a beta cell. Thus, only 16 cones converge directly through this circuit onto the ganglion cell. The tangential distribution of these cones, corresponding to the envelope of the $4 \mathrm{CBb}_{1}$ dendritic fields, is about $28 \mu \mathrm{m}$ in diameter, that is, no greater than the extent of the beta dendritic field itself. The connection between a given pair of neurons is established by many chemical synapses (*). Each cone connects to a $\mathrm{CBb}_{1}$ by about $12 *$ (Boycott and Kolb, 1973), and each $\mathrm{CBb}_{1}$ connects to a beta cell by about 38* (McGuire et al., 1986). Overall, the 16 coverging cones provide an aggregate of almost $200 *$ to the $4 \mathrm{CBb}_{1} \mathrm{~s}$, and these in turn provide an aggregate of about $150 *$ to the beta cell.

Divergence from cones to the beta cell is also narrow; in fact, it is close to the absolute minimum (Fig. 2). One cone contacts a single $\mathrm{CBb}_{1}$ that, in turn, contacts only slightly more than one beta cell. Synapses from a given bipolar are sharply restricted to a specific territory on the beta cell dendritic tree, and the overall effect is to restrict the anatomical divergence of a single cone largely to a particular region of one beta cell (Fig. 12A). These conclusions extend, but are in basic agreement with, the earlier studies of Kolb (1979) and McGuire et al. (1986).

\section{Function of the cone bipolar circuit}

Contribution to photopic receptive field properties. It seems likely that the circuit described here contributes significantly to the on-beta ganglion cell's light-adapted receptive field properties, namely, to its transient-plus-sustained on-center and its antagonistic surround. (1) The $\mathrm{CBb}_{1}$ bipolar itself has an on-center receptive field with a transient-plus-sustained response and an antagonistic surround (Nelson and Kolb, 1983). (2) The available measurements (Nelson and Kolb, 1983) suggest that the $\mathrm{CBb}_{1}$ on-center is large compared to the spacing found here between adjacent $C B b_{1} s$. This implies that the receptive fields of the 4 converging $\mathrm{CBb}_{1}$ s are essentially concentric and thus mutually reinforcing in their effects on the beta cell. (3) The 150 chemical synapses from $\mathrm{CBb}_{1}$ represent a significant input to the beta cell, about one-third of all its synaptic contacts. (4) The drug 2-amino 4-phosphonobutyric acid (APB), which blocks the light response of on-center bipolar cells (Slaughter and Miller, 1981), also blocks the response of the on-beta cell (Bolz et al., 1984).

In view of this evidence, one might have expected a good match between the extent of the beta receptive field center and the envelope of the $\mathrm{CBb}_{1}$ dendritic fields that provide its input, as suggested by McGuire et al. (1986). It turns out, however, that the envelope of the $\mathrm{CBb}_{1}$ dendritic fields in the area cen- 
A
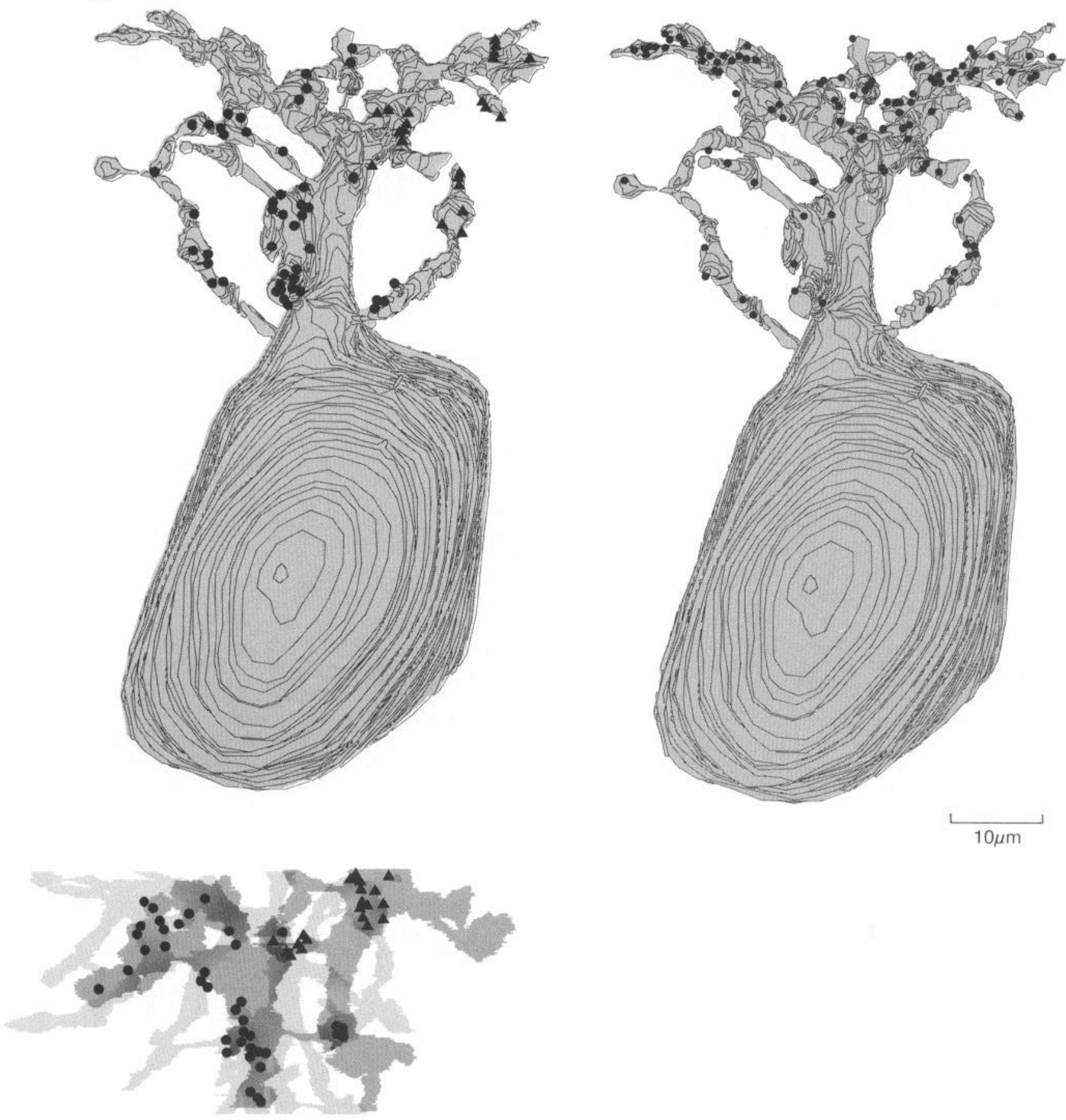

$10 \mu \mathrm{m}$

Figure 12. A, Radial view (top) of on-beta cell showing distribution of 69 contacts from adjacent $\mathrm{CBb}_{1}$ axons (cells 3, 6 in Fig. 2). Dots represent contacts from cell 3 (illustrated previously by McGuire et al., 1986), triangles represent contacts from cell 6 . Tangential view (bottom) of beta dendrites (pale) with axons of cells 3 and 6 superimposed (darker shadings). Note that, although the $\mathrm{CBb}_{1}$ axons overlap to some degree in the tangential plane, the distribution of their synapses on the beta cell do not overlap. Both $\mathrm{CBb}_{1}$ axons deliver additional contacts to beta cell dendrites (not shown) that may belong to the reconstructed cell but could not be traced to it; alternatively, these synapses may represent divergence to a different on-beta. B, Distribution of 108 amacrine contacts to the beta cell. 
tralis, spanning $28 \mu \mathrm{m}$ and covering 16 cones, resembles the beta dendritic field, 20-35 $\mu \mathrm{m}$ (Boycott and Wässle, 1974; Kolb et al., 1981), while the beta receptive field center, spanning 55$70 \mu \mathrm{m}$ (Cleland et al., 1979; Peichl and Wässle, 1979; Linsenmeier et al., 1982) and covering 60-130 cones, is much larger. One could, of course, postulate other types of bipolar or amacrine cell with wider dendritic fields to account for this discrepancy. However, the other bipolar types with input to the beta cell are generally cospatial with the $\mathrm{CBb}_{1} \mathrm{~s}$ and may not significantly enlarge the envelope of the bipolar dendritic fields (McGuire et al., 1986). Another possibility is that the $\mathrm{CBb}_{1}$ itself has a receptive field much wider than its dendritic field and great enough in extent to account for the beta receptive field without the need to postulate contributions from additional types. This is consistent with the $40 \mu \mathrm{m}$ space constant measured by Nelson and Kolb (1983) for the smallest $\mathrm{CBb}_{1}$ center; however, the eccentricity of that measurement is unknown, so the question is not entirely settled.

If the 4 cones converging on the $\mathrm{CBb}_{1}$ in the anatomical circuit provide its apparently wide center and much wider surround, it follows that the cones themselves would have large, overlapping receptive fields with a center-surround organization. This is consistent with the finding of space constants up to $180 \mu \mathrm{m}$ for cat cones (Nelson, 1977). A surround was not observed in cones by Nelson, though it has been observed in lower vertebrates (e.g., Baylor et al., 1971; Gerschenfeld and Piccolino, 1980; Murakami et al., 1982). Surround antagonism in cones is known to be particularly susceptible to damage (Pinto and Pak, 1974), so the possibility of its existence in cat cones should not be ruled out.

Parallel channels to the on-beta cell. If adjacent cones and adjacent $\mathrm{CBb}$, s have large, overlapping receptive fields, the cone bipolar circuit would consist of multiple, parallel cellular channels, 16 cones at the first stage and $4 \mathrm{CBb}_{1}$ s at the second stage, all carrying essentially the same spatial and temporal signal to the beta cell. This arrangement may help preserve the high signal-to-noise ratio present in the stimulus at photopic and mesopic intensities. The noise inherent in the stimulus is proportional to the square root of the light intensity (Rose, 1948). Additional noise that would be added by spontaneous release of synaptic transmitter in the circuit would tend to be removed by signal averaging if the same signal were transmitted via multiple channels. On the other hand, assuming that the system is linear (Shapley and Victor, 1986), it is not completely clear what advantage this design offers over others that one could imagine.

Parallel channels are also present in the cone bipolar circuit at the synaptic level: about 200 chemical synapses connect the cones to the $C B b_{1}$ s and at least 150 synapses connect the $C B b_{1}$ to the beta cell (Fig. 2). Professor R. Rodieck (unpublished observations) has pointed out to us that this feature may relate to the beta cell's ability to detect very small stimulus increments $-1 \%$ over background intensity (Enroth-Cugell et al., 1977a)- under photopic conditions. When such an increment of intensity $(I)$ is represented by $N$ discrete events, $\Delta I / I=\sqrt{N} / N$ (Dodge et al., 1968; Shapley and Enroth-Cugell, 1984); therefore, detection of a $1 \%$ increment would require at least 10,000 events to be registered by photoreceptors in the receptive field center of the ganglion cell. Rodieck further points out that to transmit this increment by means of discrete events (quantal synaptic transmission) would require modulation of at least 10,000 synaptic vesicles at each stage of the circuit. It is hard to imagine that the release of so many vesicles could be mod- ulated at a small number of synapses; it is more reasonable that 200 synapses governed hy the same signal could each modulate the release of about 50 vesicles. If this reasoning is correct, the purpose for having similar numbers of synapses at both stages in the circuit is also explained.

Function of the rod input to the cone bipolar circuit. The spatial properties of the beta cell receptive field in the mesopic range are essentially identical to its properties under photopic conditions (Enroth-Cugell et al., 1977a). This may be a simple consequence of the wide convergence by electrical synapse of rods onto cones ( 42 rods $\rightarrow 1$ cone) found here and previously in other material (Smith et al., 1986). These connections provide the pathway for the robust rod signal found in cones (Kolb, 1977; Nelson, 1977). In the mesopic range, as the signals from the cone outer segments decline (Enroth-Cugell et al., 1977b), the cone pedicles would continue to be driven by the convergent rod signals (Smith et al., 1986), and the circuits postsynaptic to the cone pedicle would continue to operate-independently of whether it is the outer segments of cones or rods that are driving them.

\section{Architecture of the rod bipolar circuit}

The rod bipolar circuit is more complex than the cone bipolar circuit. There are 5 stages instead of 3 , and both the convergence and divergence are wider, occurring in definite steps that are characteristic for each stage (Fig. 3). The overall convergence is from 1500 rods to a single $o n$-beta cell. Most of this convergence is achieved in the first 2 stages: 1500 rods $\rightarrow 100$ rod bipolars (15:1) $\rightarrow 5$ AII (20:1). Thereafter, the convergence is modest: 5 $\mathrm{AII} \rightarrow 4 \mathrm{CBb}_{1}(1.25: 1) \rightarrow 1$ on-beta (4:1). The overall divergence is small, from 1 rod to 2 on-beta cells. (This is the minimum divergence; the maximum could be as great as 4 , but the functional interpretation would be the same.) This is accomplished, however, by 3 steps of divergence: 1 rod $\rightarrow 2$ rod bipolars $\rightarrow 5$ $\mathrm{AII} \rightarrow 8 \mathrm{CBb}_{1}$ and one step of reconvergence: $8 \mathrm{CBb}_{1} \rightarrow 2$ onbeta.

The economy of chemical synapses $(*)$ in the rod bipolar circuit differs strikingly from that in the cone bipolar circuit. A rod provides only $1^{*}$ to each rod bipolar, and one rod bipolar provides $5.6^{*}$ to each AII. However, because of the additional stages and the wider divergence in the rod bipolar circuit, the aggregate number of chemical synapses mobilized by one rod is greater than for one cone:

$$
1 \text { rod } \stackrel{2^{*}}{\rightarrow} 2 \text { rod bipolar } \stackrel{50^{*}}{\rightarrow} 5 \text { AII } \rightarrow 8 \mathrm{CBb}_{1} \stackrel{400^{*}}{\rightarrow} 2 \text { on-beta. }
$$

\section{Functions of the rod bipolar circuit}

In the fully dark-adapted state, the beta cell has a center-dominated receptive field of dimensions similar to the light-adapted center (Barlow et al., 1957; Rodieck and Stone, 1965; Barlow and Levick, 1969; Sakmann and Creutzfeldt, 1969; Derrington and Lennie, 1982). The ganglion cell in this state responds to every quantal event in its receptive field with 2-3 spikes in an interval of about $50 \mathrm{msec}$ (Barlow et al., 1971; Mastronarde, 1983). In darkness it discharges continuously at about 15 spikes/ sec apparently due to quantal "dark events" arising at about 6/ sec in the field from the thermal isomerization of single rhodopsin molecules (Barlow et al., 1971; Mastronarde, 1983). Adjacent on-beta cells fire with strong temporal coupling to the same quantal event (Mastronarde, 1983).

There are several reasons to think that the rod bipolar circuit contributes significantly to these properties: (1) A quantal event 
in a rod is apparently conveyed to the inner plexiform layer via the rod bipolar (Smith et al., 1986); (2) a purely scotopic potential has been recorded by Sieving et al. (1986) and shown to originate in the IPL at the level where the rod bipolar axons terminate; (3) the rod bipolar's major target with direct access to the beta cell is the AII amacrine; (4) the time course of the $\Lambda I I ' s$ response (Nelson, 1982) matches that of the coupled firing of adjacent beta cells to the same quantal event (see Mastronarde, 1983); (5) the spatial extent of the dark-adapted beta receptive field is accounted for by the envelope of the 1500 rods converging through this circuit; (6) the beta cell's maintained discharge would be accounted for by the 1500 rods in this circuit if the rate of dark events was about $0.004 / \mathrm{rod} / \mathrm{sec}$, and this is close to the $0.0063 / \mathrm{rod} / \mathrm{sec}$ measured recently by Baylor et al. (1984) in monkey rods.

Structural basis for transmission of quantal events. A circuit to transmit a quantal signal to the on-beta cell must amplify since in the rod outer segment the signal is small, $0.7 \mathrm{pA}$ (Baylor et al., 1984). The circuit must also protect against the accumulation of additional noise since the quantal signal in the outer segment rises only modestly above the continuous dark noise, $\mathrm{S} / \mathrm{N} \leq 5$ (Baylor et al., 1984).

Two features of the rod bipolar circuit may contribute to amplification. There is divergence over the first 4 stages (1 rod $\rightarrow 2$ rod bipolars $\rightarrow 5 \mathrm{AII} \rightarrow 8 \mathrm{CBb}_{1}$ ) and thus a stepwise expansion of the number of copies of the quantal signal. Further, although the early stages employ very small numbers of chemical synapses for copying the signal (rod $\stackrel{\iota^{*}}{\rightarrow}$ rod bipolar; rod bipolar $\left.\stackrel{50^{*}}{\rightarrow} \mathrm{AII}\right)$, the last stage provides quite a large number of contacts per copy $\left(\mathrm{CBb}_{1} \stackrel{50^{*}}{\rightarrow}\right.$ on-beta). The $8 \mathrm{CBb}_{1}$ axons mobilized by a single rod provide a total output to on-beta cells of about $400 *$ (Fig. 3). These structural considerations suggest that the major step in amplification occurs at this last stage, where the number of copies of the signal has been expanded, and where there is an order of magnitude increase in the number of chemical synapses per copy.

In the first 2 stages of this circuit, which accomplish most of its convergence, the quantal signal would potentially be degraded by the accumulation of continuous dark noise. The reason, as discussed by Baylor et al. (1984), is that the continuous noise tends to increase in the postsynaptic cell as the square root of the number of rods converging. A possible solution proposed by Baylor et al. (1984) and Freed et al. (1987) is to provide each stage of major convergence with a thresholding mechanism to filter or "clip" the noise and pass the signal. Synaptic noise would potentially be greater at the last stage where there is a large increase in the number of chemical synapses. At this stage, however, the number of copies of the signal is sharply reduced (from 8 to 2 ) by reconvergence. The 8 timelocked copies of the signal would be transmitted, but the synaptic noise accompanying each copy, being temporally random, would drop out. Thus, the synaptic noise would tend to be removed by the reconvergence. The net divergence in this circuit, 1 rod $\rightarrow 2$ on-beta cells, may account for Mastronarde's (1983) observation that the same quantal event can be recorded simultaneously in 2 adjacent on-beta cells.

\section{Conclusion}

In this paper we have referred to a linear sequence of synaptically connected neurons as a "pathway." By identifying a pathway one can hope to discover the hierarchical transformations that occur between successive levels (e.g., Hubel and Wiesel, 1962;
Werblin and Dowling, 1969). Identification of a pathway does not, however, provide insight into the mechanisms of those transformations because these must be embodied in the specific patterns of connection along the pathway, that is, in what we have referred to as the "circuit." The 2 circuits described here do not nearly account for all the connections of the on-beta cell. Nevertheless, it is encouraging to find that in moving from knowledge of the pathways (Fig. 1) to knowledge of the circuits (Figs. 2, 3) one can begin to relate the anatomical structure of a circuit to its function.

\section{References}

Barlow, H. B., and W. R. Levick (1969) Changes in the maintained discharge with adaptation level in the cat retina. J. Physiol. (Lond.) 202: 699-718.

Barlow, H. B., R. Fitzhugh, and S. W. Kufficr (1957) Change of organization in the receptive fields of the cat's retina during dark adaptation. J. Physiol. (Lond.) 137: 338-354.

Barlow, H. B., W. R. Levick, and M. Yoon (1971) Responses to single quanta of light in retinal ganglion cells of the cat. Vision Res. Suppl. 3: 87-101.

Baylor, D. A., M. G. F. Fuortes, and P. M. O'Bryan (1971) Receptive fields of cones in the retina of the turtle. J. Physiol. (Lond.) 214: 265294.

Baylor, D. A., B. J. Nunn, and J. L. Schnapf (1984) The photocurrent, noise and spectral sensitivity of rods of the monkey Macaca fascicularis. J. Physiol. (Lond.) 375: 575-607.

Bolz, J., H. Wässle, and P. Thier (1984) Pharmacological modulation of on and off ganglion cells in the cat retina. Neuroscience 12: 875885 .

Boycott, B. B., and H. Kolb (1973) The connections between the bipolar cells and photoreceptors in the retina of the domestic cat. J. Comp. Neurol. 148: 91-114.

Boycott, B. B., and H. Wässle (1974) The morphological types of ganglion cells of the domestic cat's retina. J. Physiol. (Lond.) 240: $397-419$.

Boycott, B. B., L. Peichl, and H. Wässle (1978) Morphological types of horizontal cell in the retina of the domestic cat. Proc. R. Soc. Lond. [Biol.] 203: 229-245.

Cleland, B. G., T. H. Harding, and U. Tulunay-Keesey (1979) Visual resolution and receptive field size: Examination of two kinds of cat retinal ganglion cell. Science 205: 1015-1017.

Cohen, E., and P. Sterling (1986) Accumulation of $\left({ }^{3} \mathrm{H}\right)$ glycine by cone bipolar neurons in the cat retina. J. Comp. Ncurol. 250: 1-7.

Cohen, E., and P. Sterling (1987) The mosaic of cone bipolar neurons innervating the on-sublamina of the cat retina inner plexiform layer. Invest Ophthalmol. Vis. Sci. Suppl. 28: 403.

Derrington, A. M., and P. Lennie (1982) The influence of temporal frequency and adaptation level on receptive field organization of retinal ganglion cells in the cat. J. Physiol. (Lond.) 333: 343-366.

Dodge, F. A., B. W. Knight, and J. Toyoda (1968) Voltage noise in limulus visual cells. Science 160: 88-90.

Enroth-Cugell, C., B. G. Hertz, and P. Lennie (1977a) Cone signals in the cat's retina. J. Physiol. (Lond.) 269: 273-296.

Enroth-Cugell, C., B. G. Hertz, and P. Lennie (1977b) Convergence of rod and cone signals in the cat's retina. J. Physiol. (Lond.) 269: 297-318.

Famiglietti, E. V., and H. Kolb (1975) A bistratified amacrine cell and synaptic circuitry in the inner plexiform layer of the retina. Brain Res. 84: 293-300.

Famiglietti, E. V., and H. Kolb (1976) Structural basis for "ON" and "OFF"-center responses in retinal ganglion cells. Science 194: 193195.

Freed, M. A., R. G. Smith, and P. Sterling (1987) The rod bipolar array in cat retina: Pattern of input from rods and GABA-accumulating amacrine cells. J. Comp. Neurol. (in press).

Fukuda, Y., C. Hsiao, M. Watanabe, and H. Ito (1984) Morphological correlates of physiologically identified $\mathrm{Y}-, \mathrm{X}$-, and W-cells in cat retina. J. Neurophysiol. 52: 999-1013.

Gerschenfeld, H., and M. Piccolino (1980) Sustained feedback effects of L-horizontal cells on turtle cones. Proc. Soc. Lond. [Biol.] 206: 465-480. 
Holländer, H., and J. Stone (1972) Receptor pedicle density in the cat's retina. Brain Res. 42: 497-502.

Hubel, D. H., T. N. Wiesel (1962) Receptive fields, binocular interaction, and functional architecture in the cat's visual center. J. Physiol. (Lond.) 160: 106-154.

Kolb, H. (1974) The connections between horizontal cells and photoreceptors in the retina of the cat: Electron microscopy of Golgi preparations. J. Comp. Neurol. 155: 1-14.

Kolb, H. (1977) The organization of the outer plexiform layer in the retina of the cat: Electron microscopic observations. J. Neurocytol. 6: $131-153$.

Kolb, H. (1979) The inner plexiform layer in the retina of the cat: Electron microscopic observations. J. Neurocytol. 8: 295-329.

Kolb, H., and R. Nelson (1983) Rod pathways in the retina of the cat. Vis. Res. 23: 301-312.

Kolb, H., and R. Nelson (1984) Neural architecture of the cat retina. In Progress in Retinal Research, Vol. 3, N. Osborn and J. Chader, eds., pp. 21-60, Pergammon, New York.

Kolb, H., and R. W. West (1977) Synaptic connections of the interplexiform cell in the retina of the cat. J. Neurocytol. 6: 155-170.

Kolb, H., R. Nelson, and A. Mariani (1981) Amacrines, bipolars, and ganglion cells of the cat retina: A Golgi study. Vis. Res. 21: 10811114.

Linsenmeier, R. A., L. J. Frishman, H. G. Jakiela, and C. Enroth-Cugell (1982) Receptive field properties of $X$ and $Y$ cells in the cat retina derived from contrast sensitivity measurements. Vis. Res. 22: 11731183.

Mastronarde, D. N. (1983) Correlated firing of cat retinal ganglion cells. II. Responses of X-and Y-cells to single quantal events. J. Neurophysiol. 49: 325-349.

McGuire, B. A., J. K. Stevens, and P. Sterling (1984) Microcircuitry of bipolar cells in cat retina. J. Neurosci. 4: 2920-2938.

McGuire, B. A., J. K. Stevens, and P. Sterling (1986) Microcircuitry of beta ganglion cells in cat retina. J. Neurosci. 6: 907-918.

Murakami, M., Y. Shimoda, K. Nakatani, E. Miyachi, and S. Watanabe (1982) GABA-mediated negative feedhack from horizontal cells to cones in carp retina. Jpn. J. Physiol. 32: 911-926.

Nakamura, Y., B. A. McGuire, and P. Sterling (1980) Interplexiform cell in cat retina: Identification by uptake of $\gamma-\left[{ }^{3} \mathrm{H}\right]$ aminobutyric acid and serial reconstruction. Proc. Natl. Acad. Sci. USA 77: 658-661.

Nelson, R. (1977) Cat cones have rod input: A comparison of the response properties of cones and horizontal cell bodies in the retina of the cat. J. Comp. Neurol. 172: 109-136.

Nelson, R. (1982) AII amacrine cells quicken time course of rod signals in the cat retina. J. Neurophysiol. 47: 928-947.

Nelson, R., and H. Kolb (1983) Synaptic patterns and response properties of bipolar and ganglion cells in the cat retina. Vis. Res. 23. 1183-1195

Nelson, R., E. V. Famiglietti Jr., and H. Kolb (1978) Intracellular staining reveals different levels of stratification for ON- and OFFcenter ganglion cells in cat retina. J. Neurophysiol. 41: 472-483.

Peichl, L., and H. Wässle (1979) Size, scatter and coverage of ganglion cell receptive field centres in the cat retina. J. Physiol. (Lond.) 291: 117-141.

Pinto, L. H., and W. L. Pak (1974) Light-induced changes in photoreceptor membrane resistance and potential in gecko retinas. I. Preparations treated to reduce lateral interactions. J. Gen. Physiol. 64: $26-48$.
Rodieck, R. W., and J. Stone (1965) Analysis of receptive fields of cat retinal ganglion cells. J. Neurophysiol. 28: 833-849.

Rose, A. (1948) The sensitivity performance of the human eye on an absolute scale. J. Opt. Soc. Am. 38: 199-208.

Saito, H. (1983) Morphology of physiologically identified X-, Y-, and W-type retina ganglion cells of the cat. J. Comp. Neurol. 221: 279288.

Sakmann, B., and O. D. Creutzfeldt (1969) Scotopic and mesopic light adaptation in the cat's retina. Pflüegers Arch. 313: 168-185.

Shapley, R., and C. Enroth-Cugell (1984) Visual adaptation and retinal gain controls. Prog. Retinal Res. 3: 263-346.

Shapley, R., and J. Victor (1986) Hyperacuity in cat retinal ganglion cells. Science 231: 999-1002.

Sieving, P. A., L. J. Frishman, and R. H. Steinberg (1986) Scotopic threshold response of proximal retina in cat. J. Neurophysiol. 56: 1044-1061.

Slaughter, M. M., and R. F. Miller (1981) 2-Amino-4-phosphonobutyric acid: A new pharmacological tool for retinal research. Science 211: 182-184.

Smith, R. G., M. A. Freed, and P. Sterling (1986) Microcircuitry of the dark and light adapted states in the cat retina: Functional architecture of the rod-cone network. J. Neurosci. 6: 3505-3517.

Stanford, L. R., and S. M. Sherman (1984) Structure/function relationships of retinal ganglion cells in the cat. Brain Res. 297: 381-386.

Steinberg, R. H., M. Reid, and P. L. Lacy (1973) The distribution of rods and cones in the retina of the cat (Felis domesticus). J. Comp. Neurol. 148: 229-248.

Sterio, D. C. (1984) The unbiased estimation of number and sizes of arbitrary particles using the disector. J. Microscopy 134: 127-136.

Sterling, P. (1983) Microcircuitry of the cat retina. Annu. Rev. Neurosci. 6: 149-185.

Sterling, P., M. Freed, and R. G. Smith (1986) Microcircuitry and functional architecture of the cat retina. Trends Neurosci. 9: 186192.

Sterling, P., E. Cohen, M. Freed, and R. G. Smith (1987) Microcircuitry of the on-beta ganglion cell in daylight, twilight, and starlight. Neurosci. Res. (Suppl.) 6: 269-285.

Stevens, J. K., T. L. Davis, N. Friedman, and P. Sterling (1980a) A systematic approach to reconstructing microcircuitry by electron microscopy of serial sections. Brain Res. Rev. 2: 265-293.

Stevens, J. K., B. A. McGuire, and P. Sterling (1980b) Toward a functional architecture of the retina: Serial reconstruction of adjacent ganglion cells. Science 207: 317-319.

Vaney, D. I. (1985) The morphology and topographic distribution of AII amacrine cells in the cat retina. Proc. R. Soc. Lond. [Biol.] 224: 475-488.

Wässle, H., and H. J. Riemann (1978) The mosaic of nerve cells in the mammalian retina. Proc. R. Soc. Lond. [Biol.] 200: 441-461.

Wässle, H., L. Peichl, and B. B. Boycott (1978b) Topography of horizontal cells in the retina of the domestic cat. Proc. R. Soc. Lond. [Biol.] 203: 269-291.

Wässle, H., B. B. Boycott, and R. B. Illing (1981) Morphology and mosaic of on- and off-beta cells in the cat retina and some functional considerations. Proc. R. Soc. Lond. [Biol.] 212: 177-195.

Werblin, F. S., and J. E. Dowling (1969) Organization of the retina of the mudpuppy, Necturus maculosus. II. Intracellular recording. J. Neurophysiol. 32: 339-355. 